\title{
Evolution of cool-roof standards in the United States
}

\author{
Hashem Akbari and Ronnen Levinson \\ Heat Island Group \\ Lawrence Berkeley National Laboratory \\ Berkeley, CA 94720 \\ USA \\ H_Akbari@LBL.gov
}

\section{Abstract}

Roofs that have high solar reflectance and high thermal emittance stay cool in the sun. A roof with lower thermal emittance but exceptionally high solar reflectance can also stay cool in the sun. Substituting a cool roof for a noncool roof decreases cooling-electricity use, cooling-power demand, and cooling-equipment capacity requirements, while slightly increasing heating-energy consumption. Cool roofs can also lower citywide ambient air temperature in summer, slowing ozone formation and increasing human comfort.

Provisions for cool roofs in energy-efficiency standards can promote the building- and climateappropriate use of cool roofing technologies. Cool-roof requirements are designed to reduce building energy use, while energy-neutral cool-roof credits permit the use of less energy-efficient components (e.g., larger windows) in a building that has energy-saving cool roofs. Both types of measures can reduce the life-cycle cost of a building (initial cost plus lifetime energy cost).

Since 1999, several widely used building energy-efficiency standards, including ASHRAE 90.1, ASHRAE 90.2, the International Energy Conservation Code, and California's Title 24 have adopted cool-roof credits or requirements. This paper reviews the technical development of coolroof provisions in the ASHRAE 90.1, ASHRAE 90.2, and California Title 24 standards, and discusses the treatment of cool roofs in other standards and energy-efficiency programs. The techniques used to develop the ASHRAE and Title 24 cool-roof provisions can be used as models to address cool roofs in building energy-efficiency standards worldwide.

\section{Introduction}

Roofs that have high solar reflectance (high ability to reflect sunlight, spectrum $0.3-2.5 \mu \mathrm{m}$ ) and high thermal emittance (high ability to emit thermal radiation, spectrum $4-80 \mu \mathrm{m}$ ) stay cool in the sun. The same is true of roofs with lower thermal emittance but exceptionally high solar reflectance. Roofs that stay cool in the sun by minimizing solar absorption and maximizing thermal emission are hereafter denoted "cool roofs."

\section{Benefits of cool roofs}

Low roof temperatures lessen the flow of heat from the roof into the building, reducing the need for space-cooling electricity in conditioned buildings. Since building heat gain through the roof peaks in mid-to-late afternoon, when summer electricity use is highest, cool roofs can also reduce peak electricity demand. Prior research has indicated that savings are greatest for buildings located in climates with long cooling seasons and short heating seasons, particularly 
Evolution of cool roof standards in the United States

submitted to Advances in Building Energy Research, 2007-06-15

Accepted for publication, August 2007.

those buildings that have distribution ducts in the plenum (Akbari 1998; Akbari et al. 1999;

Konopacki and Akbari 1998).

Cool roofs transfer less heat to the outdoor environment than do warm roofs (Taha 2001). The resulting decrease in outside air temperature can slow urban smog formation and improve human health and outdoor comfort. Reduced thermal stress may also increase the lifetime of cool roofs, lessening maintenance and waste (Akbari et al. 2001).

Prior studies have measured daily air-conditioning energy savings and peak power demand reduction from the use of cool roofs on buildings in several warm-weather climates, including California, Florida, and Texas. Cool roofs on nonresidential buildings typically yielded measured summertime daily cooling-energy savings and peak-power demand reductions of 10 to $30 \%$, though values have been as low as $2 \%$ and as high as $40 \%$ (Table 1) (Konopacki et al. 1998). For example:

- Konopacki et al. (1998) measured summer daily cooling-energy savings of 67, 39, and 4 Wh per $\mathrm{m}^{2}$ of roof area $(18,13$, and $2 \%$ ) for three California nonresidential buildingstwo medical offices in Davis and Gilroy and a retail store in San Jose. Assuming an aged solar reflectance of 0.55 , estimated annualized cooling-energy savings (daily savings $\times$ number of cooling days per year) were $6.4,3.7$, and $0.6 \mathrm{kWh} / \mathrm{m}^{2}(16,11$, and $2 \%)$, while demand reductions were $3.3,2.4$, and $1.6 \mathrm{~W} / \mathrm{m}^{2}(12,8$, and $9 \%)$.

- Hildebrandt et al. (1998) measured summer daily cooling-energy savings of 23, 44, and $25 \mathrm{Wh} / \mathrm{m}^{2}(17,26$, and $39 \%)$ in an office, a museum, and a hospice in Sacramento, CA. Estimated annualized cooling-energy savings were $1.3,2.6$, and $2.2 \mathrm{kWh} / \mathrm{m}^{2}$, assuming an aged solar reflectance of 0.55 .

- Konopacki and Akbari (2001) estimated summer daily cooling-energy savings of 39 $\mathrm{Wh} / \mathrm{m}^{2}(11 \%)$ and a peak-power reduction of $3.8 \mathrm{~W} / \mathrm{m}^{2}(14 \%)$ in a large retail store in Austin, TX. Estimated annualized cooling-energy savings were $6.8 \mathrm{kWh} / \mathrm{m}^{2}$, assuming an aged solar reflectance of 0.55 .

- Parker et al. (1998a) measured summer daily cooling-energy savings of $44 \mathrm{Wh} / \mathrm{m}^{2}(25 \%)$ and a peak power reduction of $6.0 \mathrm{~W} / \mathrm{m}^{2}(30 \%)$ for a school building in Florida. Estimated annualized cooling-energy savings were $4.7 \mathrm{kWh} / \mathrm{m}^{2}$, assuming an aged solar reflectance of 0.55 .

Cool roofs on residential buildings yielded measured summertime cooling-energy savings and peak-power demand reductions that ranged from negligible to $80 \%$. For example:

- In a study of 11 Florida homes, Parker et al. (1998b) measured average summer daily cooling-energy savings of $7.7 \mathrm{kWh}(19 \%)$ per house and an average peak power reduction of $0.55 \mathrm{~kW}(22 \%)$ per house. .The daily electricity savings in individual houses ranged from $0.9 \mathrm{kWh}(0.2 \%)$ to $15.4 \mathrm{kWh}(45 \%)$ and the peak-power reduction ranged from $0.2 \mathrm{~kW}(12 \%)$ to $0.99 \mathrm{~kW}(23 \%)$. These initial savings resulted from increasing the solar reflectance of the shingle roofs to 0.70 from 0.08 .

- Akbari et al. (1997) measured summer daily energy savings of $14 \mathrm{Wh} / \mathrm{m}^{2}(80 \%)$ and peak demand savings of $3.8 \mathrm{~W} / \mathrm{m}^{2}(30 \%)$ in a single-story, flat-roofed house in Sacramento. The savings resulted from increasing the solar reflectance of the roof to 0.70 from 0.18 . 
Evolution of cool roof standards in the United States

submitted to Advances in Building Energy Research, 2007-06-15

Accepted for publication, August 2007.

\section{Need for cool-roof standards}

It is difficult for a building owner to assess the influence of roof properties on the lifetime cost of heating and cooling energy, which depends on (a) climate- and building-specific hourly uses of heating and cooling energy; (b) hourly valuations of energy; (c) the time value (discounting) of money; and (d) the service life of the roof. Building owners may also be unaware of the societal benefits of cool roofs, such as lower peak-power demand (reducing likelihood of power failures on hot days) and lower outdoor air temperatures (improving comfort and slowing the formation of smog). Hence, without cool-roof standards, owners will tend to choose roofs that minimize initial construction cost, rather than the aggregate cost of construction and lifetime energy consumption.

Provisions for cool roofs in energy-efficiency standards promote their building- and climateappropriate use, and also stimulate the development of energy-saving cool-roof technologies. For example, several manufacturers have introduced novel cool nonwhite roofing materials, including fiberglass asphalt shingles, clay and concrete tiles, and metal products (Akbari and Desjarlias 2005). The development and long-term performance of cool-roof technologies are described by Akbari et al. (2005a,b); Levinson et al. (2007; 2005b,c,d); and Berdahl et al. (2007).

\section{Types of requirements in standards}

Building energy-efficiency standards typically specify both mandatory and prescriptive requirements. Mandatory requirements, such as practices for the proper installation of insulation, must be implemented in all buildings subject to the standard. A prescriptive requirement typically specifies the characteristics or performance of a single component of the building (e.g., the thermal resistance of duct insulation) or of a group of components (e.g., the thermal transmittance of a roof assembly).

All buildings regulated by a particular standard must achieve either prescriptive or performance compliance. A proposed building that meets all applicable mandatory and prescriptive requirements will be in prescriptive compliance with the standard. Alternatively, a proposed building can achieve performance compliance with the standard if (a) it satisfies all applicable mandatory requirements and (b) its annual energy use does not exceed that of comparable "design" (a.k.a. "standard," or "reference") building that achieves prescriptive compliance.

Prescribing the use of cool roofs in building energy efficiency-standards promotes the costeffective use of cool roofs to save energy, reduce peak power demand, and improve air quality. Another option is to credit, rather than prescribe, the use of cool roofs. This can allow more flexibility in building design, permitting the use of less energy-efficient components (e.g., larger windows) in a building that has energy-saving cool roofs. Such credits are energy neutral, but may still reduce peak power demand and improve air quality. They may also reduce the first cost of the building.

This paper reviews the technical development of cool-roof provisions in the ASHRAE 90.1, ASHRAE 90.2, and California Title 24 building energy-efficiency standards, and discusses the treatment of cool roofs in several other standards and energy-efficiency programs. The techniques used to develop the ASHRAE and Title 24 cool-roof provisions can be used as models to address cool roofs in building energy-efficiency standards worldwide. 
Evolution of cool roof standards in the United States

submitted to Advances in Building Energy Research, 2007-06-15

Accepted for publication, August 2007.

\section{Development of standards}

In 1999, the American Society for Heating, Refrigeration, and Air-conditioning Engineers (ASHRAE) first credited cool roofs on nonresidential and high-rise residential buildings in ASHRAE Standard 90.1-1999: Energy Standards for Buildings Except Low-Rise Residential Buildings (ASHRAE 1999). In 2001, ASHRAE amended its standards for low-rise residential buildings to credit cool roofs, implementing the revisions three years later in ASHRAE Standard 90.2-2004: Energy-Efficient Design of Low-Rise Residential Buildings (ASHRAE 2004b).

In January 2001, the state of California followed the ASHRAE approach by crediting in its "Title 24" Building Energy Efficiency Standards for Residential and Nonresidential Buildings the use of cool roofing products on nonresidential buildings with low-sloped roofs (CEC 2001). In 2005, California upgraded Title 24 to prescribe minimum values of solar reflectance and thermal emittance for low-sloped roofs (i.e., roofs with a ratio of rise to run not exceeding 2:12) on nonresidential buildings (CEC 2006). As of June 2007, California is evaluating proposals to prescribe in the 2008 Title 24 standards minimum values of solar reflectance and thermal emittance for low-sloped roofs on nonresidential buildings, and for both low-sloped and steepsloped roofs on residential buildings. Other states and cities, including Florida and Chicago, IL, have adopted custom cool-roof requirements in their energy codes.

Note that the building-envelope requirements of the ASHRAE and California Title 24 standards apply only to envelope components (e.g., roofs) that enclose conditioned spaces.

\section{ASHRAE Standard 90.1}

Recognizing the potential for solar-reflective roofs to reduce the conditioning energy use of commercial buildings, the ASHRAE Standard 90.1 committee organized a task force in 1997 to analyze the energy-saving benefits of cool roofs in different climates, and to propose modifications to the standard to account for the effect of roof solar reflectance. This section summarizes the cool-roof analysis performed for ASHRAE Standard 90.1 (Akbari et al. 1998).

\section{Cool roofs versus roof insulation}

Solar-reflective roofs with high thermal emittance stay cool in the sun, reducing the flow of heat from the roof to the building's conditioned space. This can decrease the need for cooling energy in summer, and increase heating-energy use in winter. The winter heating-energy penalty is usually smaller than the summer cooling-energy savings, because in winter the sun is low, the days are short, the skies are often cloudy, and heating occurs mainly in early morning and early evening.

Roof insulation impedes the flow of heat between the roof and the conditioned space, slowing both heating of the building when the roof is warmer than the inside air and cooling of the building when the roof is cooler than the inside air. One can develop an energy-neutral tradeoff between the solar reflectance of the roof's surface and the thermal transmittance of the roof assembly.

\section{Survey of the radiative properties of roofing products}

The task force surveyed the solar reflectances and thermal emittances of various roofing products, including fiberglass asphalt shingles, elastomeric coatings, membranes, metal panels, clay tiles, and concrete tiles. The solar reflectance of shingles ranged from 0.03 to 0.26 , with 
Evolution of cool roof standards in the United States

submitted to Advances in Building Energy Research, 2007-06-15

Accepted for publication, August 2007.

most between 0.10 and 0.15 . Roofing membranes such as black single-ply roofing, smooth bitumen, gray single-ply roofing, and nominally white (actually gray) granule-surfaced bitumen exhibited solar reflectances of $0.06,0.06,0.23$, and 0.26 , respectively. Gravel roofs had solar reflectances of about 0.12 to 0.34 , depending on gravel color. The thermal emittances of these non-metallic surfaces were about 0.8 to 0.9 . Bare, shiny metal roofs have higher solar reflectance (about 0.60), but their low thermal emittances (about 0.10) make them as hot as a dark roof under low-speed winds. These data suggest that a conventional dark low-sloped roof could be conservatively assumed to have a solar reflectance of about 0.20 .

An asphalt-aluminum coating has a solar reflectance in the range of 0.30 to 0.61 . A freshly applied white elastomeric coating typically has a solar reflectance of 0.60 to 0.85 , while that of a new white single-ply roofing membrane usually exceeds 0.70 . Soiling and weathering typically reduce the solar reflectances of elastomeric and membrane white roofs by about 0.10 to 0.15 within the first year, with little change in solar reflectance thereafter. It was therefore assumed that a "cool" low-sloped roof should have an initial solar reflectance not less than 0.70 , an aged solar reflectance not less than 0.55 , and a thermal emittance not less than 0.80 .

\section{Building-energy simulations}

The DOE-2.1E building energy simulation program (DOE-2 2007) was used to estimate the influences of the solar reflectance of the roof's surface and the thermal resistance of the roof's insulation on the conditioning-energy uses of residential and nonresidential buildings with lowsloped roofs. The residential model applies to guest rooms in hotels, patient rooms in hospitals, and high-rise residential apartments. The buildings were simulated with electric cooling; gas heating; low, medium, and high levels roof insulation (insulation thermal resistances of $R=3,11$, or $38 \mathrm{ft}^{2} \mathrm{~h}^{\circ} \mathrm{F} \mathrm{BTU}^{-1}$ ); a roof thermal emittance of 0.80 ; and roof solar reflectances of $\rho=0.05$, $0.15,0.45$, and 0.75 . The 19 simulation climates ranged from very hot to very cold.

The thermal transmittance, or "U-factor," of a roof assembly is the reciprocal of the sum of the thermal resistances of the roof assembly (including insulation) and its surrounding air films. In each climate, simulated values of annual cooling-energy use (kWh), annual heating-energy use (therms), and annual conditioning-energy expenditure (dollars at $\$ 0.08 / \mathrm{kWh}$ and $\$ 0.66 /$ therm) were each regressed to the solar absorptance, $\alpha=1-\rho$, of the roof's surface, and to the thermal transmittance, $U$, of the roof assembly.

Each climate-specific energy use or energy expenditure $E$ was well-fit by an expression of the form

$$
E=C_{0}+C_{1} \alpha+C_{2} U+C_{3} U \alpha .
$$

This result was used to find combinations of roof solar absorptance $\alpha$ and roof-assembly thermal transmittance $U$ that yield equal annual energy expenditure $E$. It was also used to determine the extent to which increasing the solar reflectance of a roof from 0.20 (conventional roof) to 0.55 (aged cool roof) can decrease the need for roof insulation without increasing annual energy use. Table 2 shows for various cities the thermal resistance of insulation required under a cool roof to achieve the same annual energy use as low, medium, and high levels of insulation below a conventional roof. The use of a cool roof reduced the need for insulation in all cases, though more so in hot climates than in cold climates. 
Evolution of cool roof standards in the United States

submitted to Advances in Building Energy Research, 2007-06-15

Accepted for publication, August 2007.

\section{Cool-roof credits}

ASHRAE Standard 90.1 permits both prescriptive and performance ("energy cost budget") compliance. ASHRAE Standard 90.1-1999 includes two forms of credits for a cool roof, defined as one with a minimum initial solar reflectance of 0.70 and a minimum thermal emittance of 0.75. For performance compliance $(\$ 11.3 .6)$, a cool roof on a proposed building is assigned a solar absorptance of 0.55 (solar reflectance of 0.45 ), while a noncool roof on a proposed building and the roof on the design building are each assigned a solar absorptance of 0.70 (solar reflectance of 0.30 ). We note that the solar reflectance of 0.45 assigned to a cool proposed roof is less than that assumed in the preceding analysis; this may be a typographical error. The standard should be corrected to assign a solar reflectance of 0.55 (solar absorptance of 0.45 ) to a cool proposed roof.

For prescriptive compliance (\$5.3.1.1), ASHRAE Standard 90.1-1999 approximates the benefits of a cool roof surface by adjusting the thermal transmittance of the proposed roof assembly. The standard includes the following adjustment to the thermal transmittance of the roof assembly with a cool surface:

$$
U_{\text {roof adj }}=U_{\text {roof proposed }} \times F,
$$

where $U_{\text {roof adj }}$ is the adjusted roof thermal transmittance for use in demonstrating compliance; $U_{\text {roof proposed }}$ is the thermal transmittance of the proposed roof, as designed; and $F$ is the roof thermal-transmittance multiplier from Table 3. Since $F \leq 1$, this has the effect of decreasing the assumed thermal transmittance (increasing the assumed thermal resistance) of a proposed roofing assembly with a cool surface.

\section{Revisions}

ASHRAE Standard 90.1-2001 (ASHRAE 2001) retains the same provisions for cool-roof credits. The current version of this standard, ASHRAE Standard 90.1-2004 (ASHRAE 2004a), tabulates thermal-transmittance multipliers by U.S. climate zone (Figure 1), rather than by heating degree days (Table 4), and moves the provisions to $§ 5.5 .3 .1$.

\section{ASHRAE Standard 90.2}

The procedure for incorporating the effect of roof solar reflectance in the ASHRAE Standard 90.2 residential standards was similar to that followed for ASHRAE Standard 90.1. This section summarizes the cool-roof analysis performed for ASHRAE Standard 90.2 (Akbari et al. 2000).

\section{Building-energy simulations}

The Standard 90.2 task group used DOE-2.1E to simulate in 29 climates the influence of a solarreflective roof on the heating- and cooling-energy uses of a residential-building prototype used in previous 90.2 analyses and described by Akbari et al. (2000). Parameters varied in the prototype buildings included presence or absence of an attic; duct location (attic or conditioned space) ${ }^{1}$; thermal resistance of duct insulation $\left(2,4\right.$, or $\left.6 \mathrm{ft}^{2} \mathrm{~h}^{\circ} \mathrm{F} \mathrm{BTU} \mathrm{BT}^{-1}\right)$; roof solar reflectance $(0.10,0.25$, 0.50 , or 0.75$)$; and thermal resistance of ceiling insulation $\left(1,11,19,30\right.$ or $\left.49 \mathrm{ft}^{2} \mathrm{~h}^{\circ} \mathrm{F} \mathrm{BTU}^{-1}\right)$.

\footnotetext{
${ }^{1}$ The location of distribution ducts can strongly influence the energy performance of cooling systems. Leaky and/or poorly insulated ducts in attics have exhibited delivery efficacies as low as 50\% (Jump and Modera 1994). Delivery efficacy falls as the attic temperature rises. Parker et al. (1998a) have developed a model to account for the impact of attic temperature on the delivery efficacy of the distribution system.
} 
Evolution of cool roof standards in the United States

submitted to Advances in Building Energy Research, 2007-06-15

Accepted for publication, August 2007.

Buildings were cooled electrically, and heated with an electric heat pump, electric resistance, or natural gas. All roofs were assigned a thermal emittance of 0.80 .

In each climate, simulated values of annual cooling-energy use $(\mathrm{kWh})$, annual heating-energy use (therms), and annual conditioning energy expenditure (dollars at $\$ 0.08 / \mathrm{kWh}$ and $\$ 0.69 /$ therm) were each regressed to the solar absorptance $\alpha$ of the roof's surface, and to the thermal transmittance $U$ of the roof assembly.

Each climate-specific energy use or energy cost $E$ was well-fit by an expression of the form

$$
E=C_{0}+C_{1} U+C_{2} U^{2}+\mathrm{C}_{3} U \alpha .
$$

This result was used to find combinations of roof solar absorptance and roof-assembly thermal transmittance that yield equal annual energy cost. It was also used to determine the multiplier by which the thermal transmittance of a roof assembly can be increased without raising annual energy use when the solar reflectance of the roof's surface is increased to 0.55 (cool white steepsloped roof) from 0.10 (conventional dark steep-sloped roof). Table 5 shows this multiplier for various prototype configurations in the 29 U.S. cities simulated. Multipliers exceeded unity in all but four cities, and were at least 0.94 in all cities. That is, all but four cities exhibited positive savings, and the penalties in cold climates were small.

\section{Cool-roof credits}

ASHRAE Standard 90.2-2004 permits both prescriptive and performance (“energy cost budget") compliance. The standard includes two form of credits for a cool roof, defined as a roof with (a) a minimum initial solar reflectance of 0.65 and a minimum thermal emittance of 0.75 , and/or (b) a solar reflectance index (SRI) of at least 75 calculated under the medium wind-speed conditions specified by ASTM Standard E1980: Standard Practice for Calculating Solar Reflectance Index of Horizontal and Low-Sloped Opaque Surfaces (ASTM 1998). SRI is a relative index of the steady-state temperature of a roof's surface on a typical summer afternoon. SRI is defined to be zero for a clean black roof (solar reflectance 0.05, thermal emittance 0.90) and 100 for a clean white roof (solar reflectance 0.80, thermal emittance 0.90). Thus, warm surfaces have low SRI, and cool surfaces have high SRI.

For performance compliance (§8.8.3.1), a cool roof on a proposed building is assigned its actual solar absorptance, or possibly a solar absorptance of 0.35 ; the standard's language is ambiguous. A noncool roof on a proposed building and the roof on the design building are each assigned a solar absorptance of 0.20 (solar reflectance of 0.80 ). However, the authors believe the latter to be a typographical error, since the logical value would be a solar absorptance of 0.80 (solar reflectance of 0.20 ).

For prescriptive compliance (§5.5), ASHRAE Standard 90.2-2004 approximates the benefits of a cool roof surface by adjusting the thermal transmittance of the proposed ceiling. (The authors believe that ceiling may actually mean roof assembly.) The standard includes the following adjustment to the thermal transmittance of the ceiling under a cool roof:

$$
U_{\text {ceiling adj }}=U_{\text {ceiling proposed }} \times \text { Multiplier, }
$$

where $U_{\text {ceiling adj }}$ is the adjusted ceiling thermal transmittance for use in demonstrating compliance; $U_{\text {ceiling proposed }}$ is the thermal transmittance of the proposed ceiling, as designed; and Multiplier is the ceiling thermal transmittance multiplier from Table 6. Since Multiplier $\geq 1$, this has the effect of increasing the assumed thermal transmittance (decreasing the assumed thermal 
Evolution of cool roof standards in the United States

submitted to Advances in Building Energy Research, 2007-06-15

Accepted for publication, August 2007.

resistance) of a proposed roofing assembly with a cool surface. Hence, we believe the multipler values to be in error. It is possible that each value in Table 6 should be replaced by its reciprocal to yield multipliers that do not exceed unity.

\section{Revisions}

The current version of this standard, ASHRAE Standard 90.2-2007 (ASHRAE 2007), retains the same cool-roof credits for performance compliance. However, the cool-roof credits for prescriptive compliance have been modified. Rather than specify ceiling thermal transmittance multipliers, the new standard prescribes reduced thermal resistances for ceilings under cool roofs in climate zones 1 - 3 (Table 7).

\section{California Title 24 standards}

In 2001, cool-roof credits were added to California's Title 24 Standards. The Title 24 Standards were upgraded in 2005 to prescriptively require cool roofs on nonresidential buildings with lowsloped roofs. The California Energy Commission is currently (2007) considering adding prescriptive cool-roof requirements for all other buildings to the 2008 Standards.

\section{Cool-roof credits (2001)}

A Codes and Standards Enhancement (CASE) study prepared in 2000 by the Pacific Gas \& Electric company indicated that cool roofs would cost-effectively save energy and reduce peak power demand in California (Eilert 2000). In January 2001, the state of California followed the approach of ASHRAE Standards 90.1 and 90.2 by adding cool-roof credits to Title 24 (CEC 2001). Roofs are considered cool if they have an initial solar reflectance not less than 0.70 and a thermal emittance not less than 0.75 . An exception lowers this minimum initial solar reflectance requirement to 0.40 for tile roofs. Cool roofs were not incorporated in the prescriptive standards. For performance compliance, a cool roof on a proposed building was assigned a solar absorptance of 0.45 (solar reflectance of 0.55 ). The roof of a standard (design) building was assigned a solar absorptance of 0.70 (solar reflectance of 0.30 ), as was a noncool roof on a proposed building.

\section{Prescriptive requirements for low-sloped roofs on nonresidential buildings (2005)}

In 2002, the Berkeley Lab Heat Island Group began to investigate the prescriptive requirement in Title 24 of cool roofs for nonresidential buildings with low-sloped roofs. The analysis approach was similar to that used to develop ASHRAE Standards 90.1 and 90.2. Steps included reviewing the physics of cool roofs; reviewing measurements of cool-roof energy savings reported in the literature; investigating the market availability of cool roofs; surveying cost premiums (if any) for cool roofs; reviewing roofing-material durability; investigating the environmental consequences of cool roofs; and performing hourly simulations of building energy use to estimate the energy and peak-demand savings potentials of cool roofs (Levinson et al. 2005).

A review of low-sloped roofing technologies indicated that cool options (solar-reflective products or coatings) were available for nearly all type of low-sloped roofs, including the three dominant products: built-up roofing, modified bitumen, and single-ply membrane. A cool roof was defined as a roof with (a) an initial thermal emittance not less than 0.75 and an initial solar reflectance not less than 0.70 , and/or (b) an initial thermal emittance $\left(\varepsilon_{\text {initial }}\right)$ less than 0.75 and an initial solar reflectance not less than $0.70+0.34 \times\left(0.75-\varepsilon_{\text {initial }}\right)$. The second term in this 
Evolution of cool roof standards in the United States

submitted to Advances in Building Energy Research, 2007-06-15

Accepted for publication, August 2007.

expression is the solar-reflectance premium required to ensure that under ASTM E1980 medium wind speed conditions, the aged (weathered) temperature of a roof with low thermal emittance will not exceed that of an aged (weathered) cool roof with high thermal emittance.

DOE-2.1E building-energy simulations performed in California's 16 climate zones (Figure 2) indicate that the use of a cool roof on a prototypical California Title 24 nonresidential building with a low-sloped roof yields average annual cooling-energy savings of $3.2 \mathrm{kWh} / \mathrm{m}^{2}$, average annual natural-gas deficits of $5.6 \mathrm{MJ} / \mathrm{m}^{2}$, average source-energy savings of $30 \mathrm{MJ} / \mathrm{m}^{2}$, and average peak-power demand savings of $2.1 \mathrm{~W} / \mathrm{m}^{2}$. Total savings - initial cost savings from downsizing cooling equipment plus the 15-year net present value (NPV) of energy savings with time dependent valuation (TDV) — ranged from 1.90 to $8.30 \$ / \mathrm{m}^{2}$ (Figure 3).

The typical cost premium for a cool low-sloped roof is 0.00 to $2.2 \$ / \mathrm{m}^{2}$. Cool roofs with premiums up to $2.2 \$ / \mathrm{m}^{2}$ are expected to be cost effective in climate zones 2 through 16; those with premiums not exceeding $1.9 \$ / \mathrm{m}^{2}$ are expected to be also cost effective in climate zone 1 . Therefore, the 2005 Title 24 Standards adopted a cool-roof prescriptive requirement in all California climate zones for nonresidential buildings with low-sloped roofs. Nonresidential buildings with low-sloped roofs that do not meet this new prescriptive requirement may still achieve performance compliance.

\section{Proposed prescriptive requirements for steep-sloped non-residential roofs, steep- sloped residential roofs, and low-sloped residential roofs (2008)}

In 2005, the Berkeley Lab Heat Island Group began to investigate the merits of adding to the 2008 Title 24 Standards prescriptive requirements for the use of cool roofs on all other types of buildings, including nonresidential buildings with steep-sloped roofs, residential buildings with steep-sloped roofs, and residential buildings with low-sloped roofs. The methodology was similar to that used to consider the prescriptive requirement in the 2005 Title 24 Standards of cool low-sloped roofs for nonresidential buildings. In these 2008-cycle analyses the MICROPAS building-energy simulation tool (MICROPAS 2007) was used to simulate the hourly energy use of prototypical residential and small nonresidential buildings (Akbari et al. 2006; Wray et al. 2006).

Steep-sloped roofs on nonresidential buildings. Berkeley Lab developed a nonresidential prototype building that prescriptively complies with the 2005 Title 24 Standards. The energy use of this building was simulated with conventional and cool versions of three different steepsloped (5:12) roofing products: fiberglass asphalt shingle, concrete tile, and polymer-coated metal. Each conventional product had a solar reflectance of 0.10 . The cool shingle had a solar reflectance of 0.25, while the cool-tile and cool-metal products each had a solar reflectance of 0.40. All products were assigned a thermal emittance of 0.90 .

Total savings - initial cost savings from downsizing cooling equipment, plus the 30 -year NPV of TDV energy savings - ranged from 2.8 to $24.4 \$ / \mathrm{m}^{2}$ across California's 16 climate zones (Table 9). The typical cost premium for a cool steep-sloped roofing product is 0.0 to $2.2 \$ / \mathrm{m}^{2}$. Cool roofs with premiums up to $2.2 \$ / \mathrm{m}^{2}$ are expected to be cost effective in all 16 climate zones. At the time of writing this manuscript, California is considering including in its 2008 Title 24 Standards a prescriptive cool-roof requirement in all climate zones for nonresidential buildings with steep-sloped roofs. 
Evolution of cool roof standards in the United States

submitted to Advances in Building Energy Research, 2007-06-15

Accepted for publication, August 2007.

Low-sloped roofs on residential buildings. Berkeley Lab developed a residential prototype building that prescriptively complies with the 2005 Title 24 Standards. The energy use of this building was simulated with conventional $(\rho=0.10)$ and $\operatorname{cool}(\rho=0.55)$ versions of a low-sloped (horizontal) built-up roof.

While the 2005 Title 24 Standards prescriptively require a sub-roof radiant barrier for residential buildings in some climate zones $(2,4$, and $8-15)$, radiant barriers are not usually installed in houses with low-sloped roofs. (In climates zones where radiant barriers are prescriptively required, a house without a radiant barrier would have to demonstrate performance compliance.) Without a radiant barrier (typical of low-sloped roofs in general and pre-2000 construction in particular), total savings - initial cost savings from downsizing cooling equipment, plus the 30year NPV of TDV energy savings - ranged from -2.4 to $8.2 \$ / \mathrm{m}^{2}$ across California's 16 climate zones (Table 10). With a radiant barrier, the NPV TDV savings ranged from -2.5 to $4.7 \$ / \mathrm{m}^{2}$. The negative savings occurred in coastal California climate zones with minimal summertime cooling requirements. The presence of a sub-roof radiant barrier reduces cool-roof energy savings, just as the presence of a cool roof reduces radiant-barrier energy savings.

The typical cost premium for a cool roof is 0.0 to $2.2 \$ / \mathrm{m}^{2}$. Cool roofs with premiums up to $\$ 2.2 / \mathrm{m}^{2}$ are expected to be cost effective in some climates zones. At the time of writing this manuscript, California is considering including in its 2008 Title 24 Standards a prescriptive coolroof requirement in hot Central-Valley climates for residential buildings with low-sloped roofs.

Steep-sloped roofs on residential buildings. Berkeley Lab developed a residential prototype building that prescriptively complies with the 2005 Title 24 Standards. The energy use of this building was simulated with conventional and cool versions of three different steep-sloped (5:12) roofing products: fiberglass asphalt shingle, concrete tile, and polymer-coated metal. Each conventional product had a solar reflectance of 0.10 . The cool shingle had a solar reflectance of 0.25 , while the cool-tile and cool-metal products each had a solar reflectance of 0.40 . All products were assigned a thermal emittance of 0.90 .

The 2005 Title 24 Standards prescriptively require a sub-roof radiant barrier for residential buildings in some climate zones $(2,4$, and $8-15)$, but they are not present on most existing houses. Without a radiant barrier (typical of pre-2000 construction), total savings - initial cost savings from downsizing cooling equipment, plus the 30-year NPV of TDV energy savings ranged from -1.7 to $18.6 \$ / \mathrm{m}^{2}$ across California's 16 climate zones (Table 11). With a radiant barrier, the NPV TDV savings ranged from -1.3 to $12.1 \$ / \mathrm{m}^{2}$. Cool shingles incurred smaller saving (and penalties) than did cool tiles and cool metal products because the solar reflectance of the cool shingle exceeded that of the conventional shingle by 0.15 , rather than by 0.30 . The negative savings occur in coastal California climate zones with minimal summertime cooling requirements. The presence of a sub-roof radiant barrier reduces cool-roof energy savings, just as the presence of a cool roof reduces radiant-barrier energy savings.

The typical cost premium for a cool roof is 0.0 to $2.2 \$ / \mathrm{m}^{2}$. Cool roofs with premiums up to 2.2 $\$ / \mathrm{m}^{2}$ are expected to be cost effective in some climates zones. At the time of writing this manuscript, California is considering including in its 2008 Title 24 Standards a prescriptive coolroof requirement in hot Central-Valley climates for residential buildings with steep-sloped roofs. 
Evolution of cool roof standards in the United States

submitted to Advances in Building Energy Research, 2007-06-15

Accepted for publication, August 2007.

\section{Cool-roof provisions in other standards and programs}

Many U.S. states have adopted building energy-efficiency codes from ASHRAE Standard 90.1 or the International Energy Conservation Code (IECC). Other U.S. cities, states and territories have developed custom provisions for cool roofs in their energy codes. Aside from California, these include Atlanta, GA; Chicago, IL; Florida; Georgia; Guam; and Hawaii. Cool-roof requirements have also been developed by several voluntary energy-efficiency programs, including the U.S. Environmental Protection Agency (EPA) Energy Star ${ }^{\mathrm{TM}}$ label, the Leadership in Energy and Environmental Design (LEED) Green Building Rating System, and the cool-roof rebate programs offered by the state of California and its utilities.

An earlier report by Eley Associates (2003a) summarizes the history of cool-roof credits and requirements in these policies through 2003, with particular attention paid to the political process of their development. Here we review the treatment of cool roofs in several of these standards and programs through 2007, focusing on technical details.

\section{Standards other than ASHRAE 90.1, ASHRAE 90.2, and Title 24}

\section{International Energy Conservation Code}

The 2003 International Energy Conservation Code (IECC) does not explicitly address the use of cool roofs. However, $\S 801.2$ allows commercial buildings to comply with the 2003 IECC by satisfying the requirements of ASHRAE Standard 90.1, which in turn offers cool-roof credits. The 2003 IECC provides neither direct nor indirect cool-roof credits for residential buildings (IECC 2003).

The 2006 IECC retains the link to ASHRAE Standard 90.1 for commercial buildings, and explicitly offers cool-roof credits for residential buildings through performance compliance. Table 404.5.2(1) assigns to the roof on the reference residential building a solar absorptance of 0.75 (solar reflectance of 0.25 ) and a thermal emittance of 0.90 , while the roof on the proposed building is assigned its proposed values of solar absorptance and thermal emittance (IECC 2006).

The adoption as of May 2007 of IECC and/or ASHRAE standards by individual U.S. states is detailed in Figure 4 (commercial building codes) and Figure 5 (residential building codes).

\section{Chicago, IL}

To mitigate urban heat islands, the city of Chicago, IL added a provision to $\S 18-13-303$ of its 2001 Energy Conservation Code requiring that low-sloped roofs (those with a ratio of rise to run not greater than 2:12) exhibit an initial solar reflectance not less than 0.65 , and a solar reflectance of at least 0.50 three years after installation. Medium-sloped roofs (those with a ratio of rise to run greater than 2:12 and less than or equal to 5:12) were required to have initial and three-year solar reflectances of at least 0.15 . Both low- and medium-sloped roofs were required to have a minimum thermal emittance of 0.90 . Roofs or portions of roofs that use photovoltaic, solarthermal, or roof-garden systems were exempt from these requirements (Chicago 2001).

The cool-roof provisions of this code have been amended several times since 2001. The current (2007) code requires that low-sloped roofs installed by December 31, 2008 have an initial solar reflectance not less 0.25 , while those installed after that day must use products that qualify for the U.S. EPA Energy Star ${ }^{\text {TM }}$ label (initial and aged solar reflectances not less than 0.65 and 0.50 , respectively). Medium-sloped roofs must have an initial solar reflectance of at least 0.15 . 
Evolution of cool roof standards in the United States

submitted to Advances in Building Energy Research, 2007-06-15

Accepted for publication, August 2007.

Chicago's cool-roof standard has been weakened by the elimination of its thermal emittance requirement and the establishment of a very low minimum solar reflectance requirement for medium-sloped roofs. The effects of weakened standards on roof surface temperature are quantified below in the discussion of the Energy Star ${ }^{\mathrm{TM}}$ program.

\section{Florida}

The state of Florida first offered cool-roof credits for residential buildings in the 2001 edition of the Florida Building Code. The code's whole-building performance method for compliance (Form 600A) multiplies the area of each envelope component by a "summer point multiplier" and a "winter point multiplier" to estimate its contributions to the summer cooling load and winter heating load. A cool-roof credit introduced in 2001 allowed a proposed home with a white roof (solar reflectance $\geq 0.65$, thermal emittance $\geq 0.80$ ) to multiply its summer point multiplier by a credit factor of 0.55 and its ceiling winter point multiplier by a credit factor of 1.044 (FBC 2001, §607.1.A.5 and §607.2.A.3.6). This reduces the estimated summer ceiling heat load of a white-roofed proposed home by $45 \%$ and increases its estimated winter ceiling heat load by $4.4 \%$. The current (2004) version of the code retains this "white roof" credit (FBC 2004).

The 2007 code will use EnergyGauge ${ }^{\circledR}$ USA FlaRes2007 (EnergyGauge 2007), rather than point multipliers, to estimate the annual energy use of residential buildings (FBC 2007). EnergyGauge ${ }^{\circledR}$ USA FlaRes2007 is a building energy model based on DOE-2.1E that incorporates an improved attic model (Parker 2005). The 2007 code will require that the annual energy budget of a proposed ("as-built") home not exceed that of a reference ("baseline") home whose roof has a solar reflectance of 0.25 and a thermal emittance of 0.90 . Radiative properties that make the proposed roof cooler than the reference roof (e.g., a solar reflectance above 0.25 ) will permit the consumption of more energy elsewhere in the building. Conversely, radiative properties that make the proposed roof warmer than the reference roof (e.g., solar reflectance below 0.25 , or thermal emittance less than 0.90 ) will require increased energy efficiency in other parts of the home. The solar reflectance of 0.25 to be assigned to the roof of the reference home in the 2007 code is greater than the reference-roof solar reflectance of 0.15 used to generate the cool-roof credit factors present in the 2004 code (Parker 2007).

If the initial solar reflectance of the proposed home's roofing product has not been measured by its manufacturer, it will be set to 0.04 . If the initial thermal emittance is unmeasured, it will be assigned a value of 0.90 (FBC 2007). We note that the latter provision can significantly overestimate the true thermal emittance of a bare-metal roofing product, which is typically less than 0.20 . We address the influence of low thermal emittance on roof surface temperature in our discussion of the Energy Star ${ }^{\mathrm{TM}}$ program.

In 2004, the Florida Building Code adopted prescriptive and performance cool-roof credits for commercial buildings that are essentially the same as those in ASHRAE Standard 90.1-2004. The only difference is that the thermal-transmittance multipliers used for prescriptive compliance in §13.404.1.C.1 are mapped to Florida climate zones, rather than to U.S. climate zones (FBC 2004; Swami 2007). The proposed 2007 Florida Building Code retains the same cool-roof provisions.

\section{Hawaii}

Building energy codes in Hawaii are set by county ordinance, rather than by state law. Over $80 \%$ of the state's population lives in the counties of Honolulu and Maui (Census 2007). In 2001, the 
Evolution of cool roof standards in the United States

submitted to Advances in Building Energy Research, 2007-06-15

Accepted for publication, August 2007.

county of Honolulu amended its ordinances to prescriptively require that roof assemblies on lowrise residential buildings include at least one of the following: (a) insulation with a thermal resistance of $19 \mathrm{ft}^{2} \mathrm{~h}^{\circ} \mathrm{F} \mathrm{BTU}{ }^{-1}$; (b) two inches of continuous foam-board insulation; (c) a radiant barrier and attic ventilation; or (d) a cool roof with a solar reflectance not less than 0.70 and a thermal emittance not less than 0.75 (ROH 2001, §32-14.2). The county of Maui followed suit in 2005 (MCC 2004). The current (2007) ordinances of Honolulu and Maui retain this cool-roof requirement. The counties of Kauai and Hawaii neither credit nor prescribe the use of cool roofs on residential buildings.

In 2001, 2002, and 2005, respectively, the counties of Honolulu, Kauai, and Maui adopted coolroof credits for commercial and high-rise residential buildings based on ASHRAE Standard 90.1-1999 (Wiig 2007). The building-envelope prescriptions for these buildings (e.g., §32-8 of $\mathrm{ROH} 2004$ ) use a modified cool-roof credit adopted from the Hawaii Model Energy Code (Eley Associates 2003b). By requiring that the product of the roof thermal transmittance [BTU $\mathrm{ft}^{-2} \mathrm{~h}^{-1}$ $\left.{ }^{\circ} \mathrm{F}^{-1}\right]$, roof solar absorptance, and a radiant barrier credit $(0.33$ if present, 1 if absent) be less than $0.05 \mathrm{BTU} \mathrm{ft} \mathrm{ft}^{-2} \mathrm{~h}^{-1}{ }^{\circ} \mathrm{F}^{-1}$, this provision allows the use of reduced insulation under a roof with high solar reflectance. The envelope prescription does not set a minimum requirement for the thermal emittance of the roof. Hence, it may credit the use of a solar-reflective but hot bare-metal roof, as addressed in the discussion of the Energy Star ${ }^{\mathrm{TM}}$ program.

The county of Hawaii follows ASHRAE Standard 90.1-1989 for commercial buildings, which does neither prescribes not credits cool roofs.

\section{Guam}

Guam's code for nonresidential and high-rise residential buildings (adopted in 1995) and its code for low-rise residential buildings (adopted in 2000) establish identical prescriptive requirements for roofs on air-conditioned buildings (Eley 2007a). For these buildings, "mass" roof assemblies - i.e., roofs (i) made of concrete four inches or greater in thickness; (ii) having heat capacity per unit area greater than $7.0 \mathrm{BTU} \mathrm{ft}{ }^{-2}{ }^{\circ} \mathrm{F}^{-1}$; and/or (iii) weighing more than $35 \mathrm{lb} \mathrm{ft}^{-2}$ must have (a) a cool ("high albedo") surface of solar reflectance not less than 0.70 and thermal emittance not less than 0.75 ; (b) R-11 insulation in the interior furring space; (c) two inches of continuous insulation; and/or (d) thermal transmittance not exceeding $0.12 \mathrm{Btu} \mathrm{h}^{-1} \mathrm{ft}^{-2}{ }^{\circ} \mathrm{F}^{-1}$. Airconditioned buildings with other types of roofs are required to have more insulation and/or a lower thermal transmittance than mass roofs, but can not apply a cool roof surface toward prescriptive compliance.

Air-conditioned buildings that meet the code's mandatory requirements but not its prescriptive requirements can achieve performance compliance via either ASHRAE Standard 90.1-1989 or via a building-envelope trade-off option. The latter requires that the "energy performance factor" (EPF) of a proposed building not exceed that of a reference ("budget") building. The EPF of a building includes the EPF of its roof, which for mass roofs and roofs on metal buildings (buildings with metal sheathing and metal framing) is defined as the product of the roof's area, thermal transmittance, and solar absorptance. In EPF calculations, the solar absorptance of a proposed or reference roof is set to 0.30 if the roof is cool (solar reflectance $\geq 0.70$, thermal emittance $\geq 0.75$ ), or 0.70 otherwise. The roof of the reference building may or may not be cool, depending on whether the roof assembly chosen for the reference building uses a cool surface to comply with the code (Eley 2007b). 
Evolution of cool roof standards in the United States

submitted to Advances in Building Energy Research, 2007-06-15

Accepted for publication, August 2007.

\section{Voluntary energy-efficiency programs}

\section{U.S. EPA Energy Star ${ }^{\mathrm{TM}}$ label}

To qualify for its Energy Star ${ }^{\mathrm{TM}}$ label, the U.S. EPA currently requires that low-sloped roofing products (those applied to roofs with a ratio of rise to run not exceeding 2:12) have initial and three-year-aged solar reflectances not less than 0.65 and 0.50 , respectively. Steep-sloped roofing products (those applied to roofs with a ratio of rise to run greater than 2:12) must have initial and three-year-aged solar reflectances not less than 0.25 and 0.15, respectively (EPA 2007).

We note that the Energy Star ${ }^{\mathrm{TM}}$ cool-roof requirements have two weaknesses. First, by specifying neither a minimum thermal emittance nor a minimum solar reflectance index, they permit the use of bare-metal roofs with high solar reflectance but low thermal emittance. Under ASTM E1980 medium wind-speed conditions, the surface of an aged bare-metal roof with a solar reflectance of 0.50 and a thermal emittance of 0.15 would be about $12 \mathrm{~K}\left(22^{\circ} \mathrm{F}\right)$ hotter than that of an aged white roof with a solar reflectance of 0.50 and thermal emittance of 0.80 . Second, the minimum three-year-aged solar reflectance required for a steep-sloped roof $(0.15)$ excludes only the hottest of roofing materials, such as granule-surfaced fiberglass asphalt shingles colored with conventional dark pigments. Many cool roofing products for steep-sloped roofs attain an aged solar reflectance of at least 0.30 . Under the aforementioned conditions, the surface of a roof with a solar reflectance of 0.15 and a thermal emittance of 0.80 will be $10 \mathrm{~K}\left(18{ }^{\circ} \mathrm{F}\right)$ hotter than that of a roof with a solar reflectance of 0.30 and a thermal emittance of 0.80 .

\section{LEED Green Building Rating System}

The Leadership in Energy and Environmental Design (LEED) Green Building Rating System assigns one rating point for the use of a cool roof in its Sustainable Sites Credit 7.2 (Heat Island Effect, Roof). LEED Version 2.0 (2001) requires a cool roof to either (a) cover at least $75 \%$ of its surface with materials that have initial and three-year-aged solar reflectances of at least 0.65 and 0.50 , respectively, and a thermal emittance of at least 0.90 ; or (b) cover no less than $50 \%$ of its surface with vegetation (GBC 2001).

LEED Version 2.1 (2002) requires a cool roof to either (a) cover at least $75 \%$ of its surface with Energy-Star ${ }^{\mathrm{TM}}$ compliant products that also have a thermal emittance of at least 0.90 ; (b) cover no less than $50 \%$ of its surface covered by vegetation; or (c) cover at least $75 \%$ of its surface with a combination of these two materials (GBC 2002). Compared to version 2.0, version 2.1 reduces the minimum initial solar reflectance required for steep-sloped roofs (ratio of rise to run greater than 2:12) to 0.25 from 0.65 , and the minimum aged solar reflectance to 0.15 from 0.50 .

We note that the minimum thermal emittance requirement of 0.90 in versions 2.0 and 2.1 is unnecessarily high, as most high-emittance materials have thermal emittances in the range of 0.80 to 0.95 . The LEED requirement of 0.90 tends to exclude many cool materials, such as white roofs, whose thermal emittances may lie slightly below 0.90 . This issue is compounded by the high uncertainty (up to \pm 0.05 ) in measuring the thermal emittance of thermally massive materials. The less-stringent minimum thermal-emittance requirement of 0.75 used in the ASHRAE and Title 24 definitions of a cool roof is designed to include all high-emittance materials, most of which are expected (though not required) to exhibit thermal emittances of at least 0.80 . 
Evolution of cool roof standards in the United States

submitted to Advances in Building Energy Research, 2007-06-15

Accepted for publication, August 2007.

LEED Version 2.2 (2005) uses SRI, rather than solar reflectance, thermal emittance, or EnergyStar ${ }^{\mathrm{TM}}$ compliance, to qualify a non-vegetated cool roof (GBC 2005). LEED Version 2.2 requires a cool roof to either (a) cover at least $75 \%$ of its surface with products that have a minimum SRI of 78 (low-sloped roofs) or 29 (steep-sloped roofs); (b) have at least $50 \%$ of its surface covered by vegetation; or (c) use a combination of vegetation and high-SRI materials that satisfy a particular formula (GBC 2005).

We note that the SRI requirements in the current version of LEED (v2.2) are about those achieved by a low-sloped roof with a solar reflectance of 0.65 and a thermal emittance of 0.90 , and by a steep-sloped roof with a solar reflectance of 0.28 and a thermal emittance of 0.90 . (Since the SRI of this cool low-sloped surface is actually 78.9, we recommend that its required SRI be increased to 79 from 78.) We welcome both the simplicity of the SRI requirement and the ability to use truly cool materials whose thermal emittances are less than 0.90 .

\section{California cool-roof rebate programs}

From 2001 to 2005, the state of California and several of its utilities offered rebates of 0.10 to $0.20 \$ / \mathrm{ft}^{2}$ for the installation of cool roofs with initial solar reflectance not less than 0.70 and initial thermal emittance not less than 0.75. Since the current (2005) Title 24 Standards now prescriptively require cool roofs on nonresidential buildings with low-sloped roofs, recent rebate programs have focused in residential buildings.

In January 2006, the Sacramento Municipal Utility District (SMUD) began offering a rebate of $0.20 \$ / \mathrm{ft}^{2}$ for the installation of a residential flat roof with a solar reflectance greater than 0.75 and a thermal emittance greater than 0.75. In May 2007, the SMUD program was expanded to offer a rebate of $\$ 0.10 \$ / \mathrm{ft}^{2}$ for the installation of a steep-sloped residential roof with a solar reflectance greater than 0.40 and a thermal emittance greater than 0.75 (SMUD 2007).

In January 2007, two California utilities - Pacific Gas \& Electric (PG\&E) and Southern California Edison (SCE) - began a new program offering rebates of 0.10 to $0.20 \$ / \mathrm{ft}^{2}$ for retrofitting existing homes in certain California climates with cool roofs (PGE 2007; SCE 2007). The solar reflectance and thermal emittance requirements of this program are detailed in Table 8 . Note that all qualifying products must have a thermal emittance of at least 0.75 .

The low-sloped roof requirements of the PG\&E/SCE program are designed to promote the use of white roofs. The two levels of rebates for steep-sloped roofs (Tier 1: $0.10 \$ / \mathrm{ft}^{2}$ for solar reflectance between 0.25 and 0.39 ; Tier 2: $0.20 \$ / \mathrm{ft}^{2}$ for solar reflectance not less than 0.40 ) are designed to encourage the use of existing cool colored products (most of which lie in Tier 1) and to spur the development and sale of improved cool colored products (Tier 2).

\section{Conclusions}

Since the late 1990s, the quantification of energy savings offered by the use of cool roofs has led both ASHRAE and the state of California to add cool-roof credits and/or requirements to their energy-efficiency standards for both residential and nonresidential buildings. Many U.S. states have adopted cool-roof credits from ASHRAE Standard 90.1 (1999 or later), IECC 2003, or IECC 2006. Several U.S. cities and states other than California have developed and added custom cool-roof provisions to their energy standards. Voluntary energy-efficiency programs, such as the U.S. EPA Energy Star ${ }^{\mathrm{TM}}$ label, the LEED Green Building Rating System, and rebate programs offered by California and its utilities, have established qualifications for cool roofs. 
Evolution of cool roof standards in the United States

submitted to Advances in Building Energy Research, 2007-06-15

Accepted for publication, August 2007.

While cool-roof requirements have occasionally been too strict—e.g., excluding many cool materials by setting a minimum thermal emittance of 0.90 , rather than one of 0.75 - they are more often too lax. Particularly problematic are those definitions that (a) allow the use of hot bare-metal products on low-sloped roofs by specifying neither a minimum thermal emittance nor a minimum SRI; and/or (b) allow the use of all but the hottest materials on steep-sloped roofs by qualifying products with an aged solar reflectance as low as 0.15 . We have also found ambiguities and outright errors in several cool-roof standards. These issues suggest that more care need be taken to ensure that cool-roof standards are both accurate and effective.

The standards described herein were developed primarily by workers at several U.S. research laboratories. We expect that cool-roof standards will be further refined to incorporate improvements in building-energy analysis and cool-roof technology. However, the methods used to develop the ASHRAE and Title 24 cool-roof provisions can be used as models to address cool roofs in building-energy standards worldwide.

\section{Acknowledgments}

This work was supported by the California Energy Commission (CEC) through its Public Interest Energy Research Program (PIER), and by the Assistant Secretary for Renewable Energy under Contract No. DE-AC02-05CH1 1231.

We wish to thank Javier Ceballos, City of Chicago; Danny Parker, Jeff Sonne, and Muthusasmy Swami, Florida Solar Energy Center; Howard Wiig, State of Hawaii; and Charles Eley, Architectural Energy Corporation for clarifying building codes.

\section{References}

Akbari, H. 1998. Cool roofs save energy. ASHRAE Transactions 104(1B):783-788.

Akbari, H. and A. Desjarlais. 2005. Cooling down the house. Professional Roofing, March. Online at http://www.professionalroofing.net/article.aspx?A_ID=609 .

Akbari, H., C. Wray, T.T. Xu and R. Levinson. 2006. Inclusion of solar reflectance and thermal emittance prescriptive requirements for steep-sloped nonresidential roofs in Title 24. Online at http://energy.ca.gov/title24/2008standards/documents/2006-05-18 workshop/2006-0519 NONRESDNTL STEEP-SLOPED COOL ROOFS.PDF .

Akbari, H., M. Pomerantz, and H. Taha. 2001. Cool surfaces and shade trees to reduce energy use and improve air quality in urban areas. Solar Energy 70(3):295-310.

Akbari, H., S. Konopacki, and D. Parker. 2000. Updates on revision to ASHRAE Standard 90.2: including roof reflectivity for residential buildings. In ACEEE 2000 Summer Study on Energy Efficiency in Buildings 1:1-11 (Pacific Grove, CA; August). Washington, DC: American Council for an Energy Efficient Economy.

Akbari, H., S. Konopacki, and M. Pomerantz. 1999. Cooling energy savings potential of reflective roofs for residential and commercial buildings in the United States. Energy 24:391407.

Akbari, H., S. Konopacki, D. Parker, B. Wilcox, C. Eley, and M. Van Geem. 1998. Calculations in Support of SSP90.1 for Reflective Roofs. ASHRAE Transactions, 104(1B), pp. 984-995. 
Evolution of cool roof standards in the United States

submitted to Advances in Building Energy Research, 2007-06-15

Accepted for publication, August 2007.

Akbari, H., R. Levinson, and P. Berdahl. 2005a. Review of residential roofing materials, Part I: a review of methods for the manufacture of residential roofing materials. Western Roofing Insulation and Siding. Jan/Feb, pp. 54-57.

Akbari, H., R. Levinson, and P. Berdahl. 2005b. Review of residential roofing materials, Part II: a review of methods for the manufacture of residential roofing materials. Western Roofing Insulation and Siding. Mar/Apr, pp. 52-58.

ASHRAE. 1999. ASHRAE Standard 90.1-1999: Energy Standard for Buildings Except LowRise Residential Buildings, SI Edition. Atlanta, GA: American Society of Heating, Refrigerating, and Air-Conditioning Engineers.

ASHRAE. 2001. ASHRAE Standard 90.1-2001: Energy Standard for Buildings Except LowRise Residential Buildings, SI Edition. Atlanta, GA: American Society of Heating, Refrigerating, and Air-Conditioning Engineers.

ASHRAE. 2004a. ASHRAE Standard 90.1-2004: Energy Standard for Buildings Except LowRise Residential Buildings, SI Edition. Atlanta, GA: American Society of Heating, Refrigerating, and Air-Conditioning Engineers.

ASHRAE. 2004b. ASHRAE Standard 90.2-2004: Energy-Efficient Design of Low-Rise Residential Buildings. Atlanta, GA: American Society of Heating, Refrigerating, and AirConditioning Engineers.

ASHRAE. 2007. ASHRAE Standard 90.2-2007: Energy-Efficient Design of Low-Rise Residential Buildings. Atlanta, GA: American Society of Heating, Refrigerating, and AirConditioning Engineers.

ASTM. 1998. ASTM E 1980-98: Standard Practice for Calculating Solar Reflectance Index of Horizontal and Low-Sloped Opaque Surfaces. In Annual Book of ASTM Standards, Vol. 04.12. Philadelphia, PA: American Society for Testing and Materials.

BCAP. 2007. Status of residential and commercial building state energy codes. Online at http://www.bcap-energy.org/map page.php .

Berdahl, P., H. Akbari, R. Levinson, and W. A. Miller. 2007. Weathering of roofing materials An overview. In press at Construction and Building Materials (available online 15 Dec 2006).

CEC. 2001. 2001 Energy Efficiency Standards for Residential and Nonresidential Buildings. P400-01-024. Sacramento, CA: California Energy Commission.

CEC. 2006. 2005 Building Energy Efficiency Standards for Residential and Nonresidential Buildings. CEC-400-2006-015. Sacramento, CA; California Energy Commission.

Census. 2007. U.S. Census Bureau State and County Quickfacts. Online at http://quickfacts.census.gov .

Chicago. 2001. Amendment of Title 18 of Municipal Code of Chicago concerning energy efficiency requirements. Journal of the City Council of Chicago, June 6, p. 60939.

Chicago. 2007. City of Chicago Energy Conservation Code. Chicago, IL: Index Publishing Corporation.

DOE-2. 2007. Lawrence Berkeley National Lab DOE-2 website. Online at http://simulationresearch.lbl.gov/dirsoft/d2whatis.html . 
Evolution of cool roof standards in the United States

submitted to Advances in Building Energy Research, 2007-06-15

Accepted for publication, August 2007.

Eley Associates. 2003a. Assessment of public policies affecting cool metal roofs. Final report prepared for the Cool Metal Roofing Coalition. Online at http://www.coolmetalroofing.org/elements/uploads/casestudies/TMI_CaseStudy_28.pdf.

Eley Associates. 2003b. Hawaii Commercial Building Guidelines for Energy Efficiency. Online at http://www.archenergy.com/library/general/hawaiigl//

Eley. 2007a. Guam Building Energy Code. Online at http://eley.com/guam .

Eley. 2007b. Personal communication with Charles Eley, Architectural Energy Corporation, August 17.

Eilert, P. 2000. High albedo (cool) roofs: codes and standards enhancement (CASE) study.

Pacific Gas \& Electric report. Online at

http://www.energy.ca.gov/title24/2001standards/associated documents/2000-11-

17 PGE_CASE.PDF.

EnergyGauge. 2007. EnergyGauge ${ }^{\circledR}$ USA FlaRes2007 energy and economic analysis software. Online at http://www.energygauge.com .

EPA. 2007. Roof products criteria for U.S. EPA Energy Star ${ }^{\mathrm{TM}}$ program. Online at http://www.energystar.gov/index.cfm?c=roof prods.pr_crit roof products .

FBC. 2001. 2001 Florida Building Code. Tallahassee, FL: Florida Building Commission. Online at http://www.floridabuilding.org/

FBC. 2004. 2004 Florida Building Code. Tallahassee, FL: Florida Building Commission. Online at http://www.floridabuilding.org/

FBC. 2007. Proposed modification to the Florida Building Code: Chapter 11, Energy Efficiency. Online at http://www.dca.state.fl.us/FBC/thecode/Res_Chapter_11.rtf .

GBC. 2001. Leadership in Energy and Environmental Design Green Building Rating System for new construction and major renovations (LEED-NC), version 2.0. U.S. Green Building Council. Online at https://www.usgbc.org .

GBC. 2002. Leadership in Energy and Environmental Design Green Building Rating System for new construction and major renovations (LEED-NC), version 2.1. U.S. Green Building Council. Online at https://www.usgbc.org.

GBC. 2005. Leadership in Energy and Environmental Design Green Building Rating System for new construction and major renovations (LEED-NC), version 2.2. U.S. Green Building Council. Online at https://www.usgbc.org/.

Hildebrandt, E., W. Bos, and R. Moore. 1998. Assessing the impacts of white roofs on building energy loads. ASHRAE Technical Data Bulletin 14(2):28-36. Atlanta, GA: American Society of Heating, Refrigerating, and Air-Conditioning Engineers.

Jump, D. and M. Modera. 1994. Energy impacts of attic duct retrofits in Sacramento houses. LBL-35375. Berkeley, CA: Lawrence Berkeley National Laboratory.

Konopacki, S. and H. Akbari. 1998. Simulated impact of roof surface solar absorptance, attic, and duct insulation on cooling and heating energy use in single-family new residential buildings. LBNL-41834. Berkeley, CA: Lawrence Berkeley National Laboratory. 
Evolution of cool roof standards in the United States

submitted to Advances in Building Energy Research, 2007-06-15

Accepted for publication, August 2007.

Konopacki, S. and H. Akbari. 2001. Measured energy savings and demand reduction from a reflective roof membrane on a large retail store in Austin. LBNL-47149. Berkeley, CA: Lawrence Berkeley National Laboratory.

Konopacki, S., L. Gartland, H. Akbari, and L. Rainer. 1998. Demonstration of energy savings of cool roofs. LBNL-40673. Berkeley, CA: Lawrence Berkeley National Laboratory.

Levinson, R., H. Akbari, S. Konopacki, and S. Bretz. 2005a. Inclusion of cool roofs in nonresidential Title 24 prescriptive requirements. Energy Policy 33 (2), 151-170.

Levinson, R., P. Berdahl and H. Akbari. 2005b. Solar spectral optical properties of pigments, part I: Model for deriving scattering and absorption coefficients from transmittance and reflectance measurements. Solar Energy Materials \& Solar Cells 89, 319-349.

Levinson, R., P. Berdahl and H. Akbari. 2005c. Solar spectral optical properties of pigments, part II: Survey of common colorants. Solar Energy Materials \& Solar Cells 89, 351-389.

Levinson, R., P. Berdahl, H. Abkari, W. Miller, I. Joedicke, J. Reilly, Y. Suzuki and M. Vondran. 2007. Methods of creating solar-reflective nonwhite surfaces and their application to residential roofing materials. Solar Energy Materials \& Solar Cells 91, 304-314.

Levinson, R., P. Berdahl, A.A. Berhe and H. Akbari. 2005d. Effects of soiling and cleaning on the reflectance and solar heat gain of a light-colored roofing membrane. Atmospheric

Environment 39, 7807-7824.

MCC. 2004. A bill for an ordinance amending Title 16, Maui County Code, pertaining to energy efficiency standards for buildings. Online at http://www.co.maui.hi.us/files/ordinance/LFOrd3240_etkoujogl.pdf.

MICROPAS. 2007. MICROPAS product website. Online at http://micropas.com/ .

Parker, D. 2005. Technical support for development of an attic simulation model for the California Energy Commission. Florida Solar Energy Center report FSEC-CR-1526-05. Online at http://www.fsec.ucf.edu/en/publications/pdf/FSEC-CR-1526-05.pdf .

Parker, D. 2007. Personal communication from Danny Parker, Florida Solar Energy Center, August 13.

Parker, D., J. Huang, S. Konopacki, L. Gartland, J. Sherwin, and L. Gu. 1998a. Measured and simulated performance of reflective roofing systems in residential buildings. ASHRAE Transactions 104(1), Atlanta, GA.

Parker, D., J. Sherwin, and J. Sonne. 1998b. Measured performance of a reflective roofing system in a Florida commercial building. ASHRAE Technical Data Bulletin 14(2):7-12. Atlanta, GA: American Society of Heating, Refrigerating, and Air-Conditioning Engineers.

PGE. 2007. Pacific Gas \& Electric cool-roof rebate program. Online at http://www.pge.com/res/rebates/cool_roof/ .

ROH. 2001. Revised ordinances of Honolulu, 2001.

ROH. 2007. Revised ordinances of Honolulu. Online at http://www.honolulu.gov/refs/roh .

SCE. 2007. Southern California Edison cool-roof rebate program. Online at http://www.sce.com/RebatesandSavings/Residential/_Heating+and+Cooling/CoolRoof/. 
Evolution of cool roof standards in the United States

submitted to Advances in Building Energy Research, 2007-06-15

Accepted for publication, August 2007.

SMUD. 2007. Sacramento Municipal Utility District residential cool-roof program. Online at http://www.smud.org/rebates/cool\%20roofs .

Swami, M. 2007. Personal communication from Muthusamy Swami, Florida Solar Energy Commission, developer of FLA/COM performance compliance software, June 14.

Taha, H. 2001. Potential impacts of climate change on tropospheric ozone in California: a preliminary episodic modeling assessment of the Los Angeles Basin and the Sacramento Valley. LBNL-46695. Berkeley, CA: Lawrence Berkeley National Laboratory.

Wiig, H. 2007. Personal communication from Howard Wiig, Institutional Energy Analyst, Department of Business, Economic Dev. and Tourism, Hawaii, June 14.

Wray, C., H. Akbari , T.T. Xu and R. Levinson. 2006. Inclusion of solar reflectance and thermal emittance prescriptive requirements for residential roofs in Title 24. Online at http://energy.ca.gov/title24/2008standards/documents/2006-05-18 workshop/2006-0517 RESIDENTIAL_ROOFS.PDF . 
Evolution of cool roof standards in the United States

submitted to Advances in Building Energy Research, 2007-06-15

Accepted for publication, August 2007.

Table 1. Cool-roof energy savings measured in six California nonresidential buildings (a-c:

Konopacki et al. 1998; d-f: Hildebrandt et al. 1998)

\begin{tabular}{|c|c|c|c|c|c|c|}
\hline & $\begin{array}{c}\text { a. Davis } \\
\text { medical office }\end{array}$ & $\begin{array}{c}\text { b. Gilroy } \\
\text { medical office }\end{array}$ & $\begin{array}{l}\text { c. San Jose } \\
\text { retail store }\end{array}$ & $\begin{array}{l}\text { d. Sacramento } \\
\text { office }\end{array}$ & $\begin{array}{l}\text { e. Sacramento } \\
\text { museum }\end{array}$ & $\begin{array}{c}\text { f. } \\
\begin{array}{c}\text { Sacramento } \\
\text { hospice }\end{array}\end{array}$ \\
\hline \multicolumn{7}{|l|}{ ROOF } \\
\hline area $\left(\mathrm{m}^{2}\right)$ & 2,950 & 2,210 & 3,060 & 2,290 & 455 & 557 \\
\hline type & built-up & built-up & built-up & $\begin{array}{l}\text { 4-ply with } \\
\text { capsheet }\end{array}$ & built-up gravel & $\begin{array}{l}\text { composite } \\
\text { shingle/ } \\
\text { flat built-up }\end{array}$ \\
\hline material & $\begin{array}{l}\text { asphalt capsheet } \\
\text { with light gray } \\
\text { granules }\end{array}$ & $\begin{array}{c}\text { asphalt } \\
\text { capsheet } \\
\text { with light gray } \\
\text { granules }\end{array}$ & $\begin{array}{c}\text { asphalt } \\
\text { capsheet } \\
\text { with tan } \\
\text { granules }\end{array}$ & $\begin{array}{l}\text { asphalt capsheet } \\
\text { with light gray } \\
\text { granules }\end{array}$ & $\begin{array}{c}\text { asphalt capsheet } \\
\text { with light gray } \\
\text { granules }\end{array}$ & $\begin{array}{l}\text { asphalt } \\
\text { capsheet } \\
\text { with tan } \\
\text { granules }\end{array}$ \\
\hline $\begin{array}{l}\text { insulation } \\
\left(\mathrm{m}^{2} \mathrm{~K} / \mathrm{W}\right)\end{array}$ & $\begin{array}{c}1.4 \\
\text { (R-8 rigid) }\end{array}$ & $\begin{array}{c}3.4 \\
\text { (R-19 } \\
\text { fiberglass) }\end{array}$ & radiant barrier & $\begin{array}{c}3.4 \\
(\mathrm{R}-19)\end{array}$ & none & $\begin{array}{c}1.9 \\
(\mathrm{R}-11)\end{array}$ \\
\hline structure & metal deck & wood deck & wood deck & metal deck & wood deck & wood deck \\
\hline plenum type & return plenum & $\begin{array}{l}\text { ventilated } \\
\text { plenum }\end{array}$ & $\begin{array}{l}\text { ventilated } \\
\text { plenum }\end{array}$ & return plenum & ventilated plenum & $\begin{array}{l}\text { ventilated } \\
\text { plenum }\end{array}$ \\
\hline ceiling type & tiles & tiles & tiles & tiles & tiles & tiles \\
\hline $\begin{array}{l}\text { pre-coating } \\
\text { condition }\end{array}$ & $\begin{array}{l}25 \% \text { granule } \\
\text { loss and } \\
\text { bubbling }\end{array}$ & $\begin{array}{l}25 \% \text { granule } \\
\text { loss and } \\
\text { cracking }\end{array}$ & $\begin{array}{l}25 \% \text { granule } \\
\text { loss and } \\
\text { cracking }\end{array}$ & $\begin{array}{l}25 \% \text { granule loss } \\
\text { and bubbling }\end{array}$ & $\begin{array}{l}25 \% \text { granule loss } \\
\text { and cracking }\end{array}$ & $\begin{array}{l}25 \% \text { granule } \\
\text { loss and } \\
\text { cracking }\end{array}$ \\
\hline $\begin{array}{c}\text { pre-coating } \\
\text { solar reflectance }\end{array}$ & 0.24 & 0.25 & 0.16 & 0.24 & 0.25 & 0.16 \\
\hline $\begin{array}{l}\text { post-coating } \\
\text { solar reflectance } \\
\text { after } 1 \text { year }\end{array}$ & 0.60 & 0.60 & 0.60 & 0.60 & 0.60 & 0.60 \\
\hline $\begin{array}{c}\text { degraded } \\
\text { (weathered) } \\
\text { solar reflectance }\end{array}$ & 0.55 & 0.55 & 0.55 & 0.55 & 0.55 & 0.55 \\
\hline \multicolumn{7}{|l|}{ SUPPLY DUCT } \\
\hline $\begin{array}{l}\text { insulation } \\
\left(\mathrm{m}^{2} \mathrm{~K} / \mathrm{W}\right)\end{array}$ & none & $\begin{array}{c}0.81 \\
(R-4.6)\end{array}$ & $\begin{array}{l}0.35 \\
(\mathrm{R}-2)\end{array}$ & none & $\begin{array}{c}0.81 \\
(R-4.6)\end{array}$ & $\begin{array}{l}0.35 \\
(R-2)\end{array}$ \\
\hline location & $\begin{array}{l}\text { conditioned } \\
\text { space }\end{array}$ & plenum & plenum & $\begin{array}{l}\text { conditioned } \\
\text { space }\end{array}$ & plenum & plenum \\
\hline \multicolumn{7}{|l|}{ SAVINGS } \\
\hline $\begin{array}{c}\text { measured daily } \\
\text { cooling-energy } \\
\text { savings } \\
\left(\mathrm{Wh} / \mathrm{m}^{2}\right)\end{array}$ & $67(18 \%)$ & $39(13 \%)$ & $4(2 \%)$ & $23(17 \%)$ & $44(26 \%)$ & $25(39 \%)$ \\
\hline cooling days/year & 110 & 110 & 165 & 165 & 165 & 165 \\
\hline $\begin{array}{c}\text { degraded annual } \\
\text { cooling-energy } \\
\text { savings } \\
\left(\mathrm{kWh} / \mathrm{m}^{2}\right)\end{array}$ & 6.4 & 3.7 & 0.6 & 1.3 & 2.6 & 2.2 \\
\hline $\begin{array}{l}\text { degraded peak- } \\
\text { power demand } \\
\text { reduction }\left(\mathrm{W} / \mathrm{m}^{2}\right)\end{array}$ & 3.3 & 2.4 & 1.6 & $\mathrm{n} / \mathrm{a}$ & $\mathrm{n} / \mathrm{a}$ & $\mathrm{n} / \mathrm{a}$ \\
\hline
\end{tabular}


Evolution of cool roof standards in the United States

submitted to Advances in Building Energy Research, 2007-06-15

Accepted for publication, August 2007.

Table 2. Thermal resistance of insulation below a cool roof (solar reflectance 0.55 ) that yields the same annual energy expenditure (cost at $\$ 0.66 /$ therm and $\$ 0.08 / \mathrm{kWh}$ ) as a low, medium or high level of insulation $\left(3,11\right.$, or $38 \mathrm{ft}^{2} \mathrm{~h}^{\circ} \mathrm{F} \mathrm{BTU} \mathrm{BT}^{-1}$ ) below a conventional roof (solar reflectance $0.20)$.

\begin{tabular}{|c|c|c|c|c|c|c|c|}
\hline \multirow{2}{*}{ location } & \multirow{2}{*}{ CDD50 $^{\mathrm{a}}$} & \multicolumn{3}{|c|}{ residential building } & \multicolumn{3}{c|}{ non-residential building } \\
\cline { 3 - 8 } & & $\mathrm{R}=3$ & $\mathrm{R}=11$ & $\mathrm{R}=38$ & $\mathrm{R}=3$ & $\mathrm{R}=11$ & $\mathrm{R}=38$ \\
\hline \hline Honolulu, HI & 9804 & -0.3 & 3.5 & 19.4 & 0.0 & 3.9 & 16.5 \\
\hline Miami, FL & 9261 & 0.1 & 4.3 & 21.0 & 0.3 & 4.5 & 18.2 \\
\hline Tampa, FL & 8022 & 0.4 & 4.9 & 21.4 & 0.5 & 5.0 & 19.2 \\
\hline Phoenix, AZ & 7858 & 0.9 & 6.2 & 26.2 & 0.9 & 5.9 & 22.0 \\
\hline Lake Charles, LA & 6860 & 0.7 & 5.6 & 24.2 & 0.7 & 5.5 & 21.3 \\
\hline San Diego, CA & 5170 & 0.1 & 4.2 & 19.6 & 0.2 & 4.2 & 16.5 \\
\hline Fort Worth, TX & 6200 & 1.1 & 6.7 & 27.5 & 1.1 & 6.4 & 23.5 \\
\hline San Bernardino, CA & 4854 & 0.9 & 6.0 & 23.9 & 0.9 & 5.7 & 21.1 \\
\hline Atlanta, GA & 4922 & 1.0 & 6.4 & 25.9 & 1.0 & 6.1 & 22.4 \\
\hline San Francisco, CA & 2486 & 1.7 & 8.1 & 31.2 & 1.3 & 6.9 & 24.8 \\
\hline Amarillo, TX & 4262 & 1.4 & 7.4 & 29.5 & 1.4 & 7.1 & 26.1 \\
\hline Portland, OR & 2320 & 2.0 & 8.6 & 31.4 & 1.8 & 8.0 & 27.4 \\
\hline Seattle, WA & 1716 & 2.2 & 9.2 & 33.9 & 1.9 & 8.3 & 28.6 \\
\hline Boise, ID & 2748 & 1.9 & 8.4 & 31.7 & 1.8 & 7.9 & 27.7 \\
\hline Vancouver, Canada & 1468 & 2.2 & 9.1 & 32.0 & 1.9 & 8.3 & 28.5 \\
\hline Minneapolis, MN & 2701 & 2.4 & 9.7 & 34.5 & 2.1 & 8.9 & 31.2 \\
\hline Halifax, Canada & 1447 & 2.4 & 9.7 & 35.1 & 2.2 & 9.2 & 32.2 \\
\hline Bismarck, ND & 2222 & 2.3 & 9.4 & 33.5 & 2.2 & 9.0 & 31.5 \\
\hline Anchorage, AK & 684 & 3.0 & 10.9 & 36.8 & 2.6 & 10.0 & 34.4 \\
\hline Edmonton, Canada & 880 & 2.8 & 10.4 & 36.0 & 2.5 & 9.7 & 33.3 \\
\hline
\end{tabular}

a. Cooling degree days based on $50^{\circ} \mathrm{F}$.

Table 3. Roof thermal-transmittance (U-factor) multipliers for cool roofs on buildings other than low-rise residential buildings (Table 5.3.3.1B of ASHRAE 90.1-1999).

\begin{tabular}{|c|c|c|}
\hline HDD65 $^{\mathrm{a}}$ & $(\text { HDD18 })^{\mathrm{b}}$ & roof U-factor multiplier \\
\hline $0-900$ & $(0-500)$ & 0.77 \\
\hline $901-1800$ & $(501-1000)$ & 0.83 \\
\hline $1801-2700$ & $(1001-1500)$ & 0.85 \\
\hline $2799-3600$ & $(1501-2000)$ & 0.86 \\
\hline$>3600$ & $(>2000)$ & 1.00 \\
\hline
\end{tabular}

a. Heating degree days based on $65^{\circ} \mathrm{F}$

b. Heating degree days based on $18^{\circ} \mathrm{C}$ 
Evolution of cool roof standards in the United States

submitted to Advances in Building Energy Research, 2007-06-15

Accepted for publication, August 2007.

Table 4. Roof thermal transmittance (U-factor) multipliers for cool roofs on buildings other than low-rise residential buildings (Table 5.5.3.1 of ASHRAE 90.1-2004).

\begin{tabular}{|c|c|}
\hline climate zone & roof U-factor multiplier \\
\hline 1 & 0.77 \\
\hline 2 & 0.83 \\
\hline 3 & 0.85 \\
\hline $4-8$ & 1 \\
\hline
\end{tabular}


Evolution of cool roof standards in the United States

submitted to Advances in Building Energy Research, 2007-06-15

Accepted for publication, August 2007.

Table 5. Multiplier by which the thermal transmittance (U-factor) of a residential roof assembly can be increased without raising annual energy use when the solar reflectance of the roof's surface is increased to 0.55 (cool) from 0.10 (conventional). Ducts in the attics have R-4 insulation $\left(4 \mathrm{ft}^{2} \mathrm{~h}^{\circ} \mathrm{F} \mathrm{BTU}{ }^{-1}\right)$; ducts in the conditioned space are uninsulated.

\begin{tabular}{|c|c|c|c|c|c|}
\hline \multirow[b]{2}{*}{ location } & \multirow[b]{2}{*}{$\mathrm{CDD}^{\mathrm{a}}{ }^{\mathrm{a}}$} & \multirow[b]{2}{*}{ HDD65 $5^{\mathrm{b}}$} & \multicolumn{3}{|c|}{ Multiplier } \\
\hline & & & duct in attics & $\begin{array}{l}\text { ducts in conditioned } \\
\text { space }\end{array}$ & $\begin{array}{l}\text { roofs with no } \\
\text { attics }\end{array}$ \\
\hline Honolulu, $\mathrm{HI}$ & 4329 & 0 & 2.62 & 2.62 & 1.69 \\
\hline Miami, FL & 4127 & 141 & 2.19 & 2.19 & 1.67 \\
\hline Brownsville, TX & 3563 & 659 & 1.60 & 1.60 & 1.61 \\
\hline Phoenix, AZ & 3815 & 1154 & 1.53 & 1.53 & 2.39 \\
\hline Jacksonville, FL & 2657 & 1437 & 1.52 & 1.52 & 1.59 \\
\hline Tucson, AZ & 2763 & 1554 & 1.49 & 1.49 & 2.76 \\
\hline Lake Charles, LA & 2624 & 1683 & 1.46 & 1.46 & 2.02 \\
\hline El Paso, TX & 2046 & 2597 & 1.42 & 1.42 & 1.68 \\
\hline Los Angeles, CA & 943 & 1309 & 1.38 & 1.38 & 1.64 \\
\hline San Diego, CA & 766 & 1076 & 1.37 & 1.37 & 1.69 \\
\hline Las Vegas, NV & 3067 & 2293 & 1.37 & 1.37 & 1.65 \\
\hline Fresno, CA & 1884 & 2602 & 1.34 & 1.34 & 1.56 \\
\hline Charleston, SC & 2010 & 2209 & 1.33 & 1.33 & 1.58 \\
\hline Fort Worth, TX & 2415 & 2304 & 1.31 & 1.31 & 1.64 \\
\hline Fort Smith, AR & 1895 & 3351 & 1.24 & 1.24 & 1.63 \\
\hline Sacramento, CA & 1144 & 2794 & 1.22 & 1.22 & 1.61 \\
\hline Albuquerque, NM & 1211 & 4361 & 1.19 & 1.19 & 1.4 \\
\hline Los_Angeles, CA & 470 & 1291 & 1.16 & 1.16 & 1.55 \\
\hline St. Louis, MO & 1437 & 5021 & 1.11 & 1.11 & 1.5 \\
\hline Washington, DC & 1044 & 5233 & 1.09 & 1.09 & 1.23 \\
\hline Dodge, KS & 1371 & 5353 & 1.09 & 1.09 & 1.34 \\
\hline North Omaha, NE & 1051 & 6047 & 1.08 & 1.08 & 1.27 \\
\hline Denver, CO & 623 & 6007 & 1.06 & 1.06 & 1.33 \\
\hline Winnemucca, NV & 604 & 6444 & 1.06 & 1.06 & 1.28 \\
\hline New York, NY & 1002 & 5090 & 1.05 & 1.05 & 1.28 \\
\hline Bismarck, ND & 408 & 8666 & 1.02 & 1.02 & 1.25 \\
\hline Redmond, OR & 194 & 6732 & 1.01 & 1.01 & 1.26 \\
\hline Madison, WI & 521 & 7495 & 1.01 & 1.01 & 1.18 \\
\hline Seattle, WA & 127 & 4867 & 0.97 & 0.97 & 1.12 \\
\hline Fairbanks, AK & 29 & 14095 & 0.97 & 0.97 & 1.09 \\
\hline Kwajalein, PI & 0 & 11126 & 0.95 & 0.95 & 0.93 \\
\hline San Francisco, CA & 69 & 3239 & 0.94 & 0.94 & 0.98 \\
\hline
\end{tabular}

a. Cooling degree days based on $65^{\circ} \mathrm{F}$

b. Heating degree days based on $65^{\circ} \mathrm{F}$ 
Evolution of cool roof standards in the United States

submitted to Advances in Building Energy Research, 2007-06-15

Accepted for publication, August 2007.

Table 6. Ceiling thermal-transmittance (U-factor) multipliers for residential cool roofs (Table 5.5 of ASHRAE 90.2-2004). It is possible that these multipliers should be replaced by their reciprocals to yield values less than or equal to unity.

\begin{tabular}{|c|c|c|}
\hline zone & ceilings with attics & ceilings without attics \\
\hline 1 & 1.50 & 1.30 \\
\hline 2 & 1.25 & 1.30 \\
\hline 3 & 1.20 & 1.20 \\
\hline 4 & 1.15 & 1.20 \\
\hline 5 & 1.10 & 1.10 \\
\hline $6,7,8$ & 1.00 & 1.00 \\
\hline
\end{tabular}

Table 7. Ceiling thermal resistances $\left(\mathrm{ft}^{2} \mathrm{~h}^{\circ} \mathrm{F} \mathrm{BTU}^{-1}\right)$ prescribed by ASHRAE Standard 90.22007 for ceilings under conventional (non-cool) and cool residential roofs, derived from Tables 5.2 and 5.6.1 of ASHRAE Standard 90.2-2007 (ASHRAE 2007). Reduced requirements for cool-roofed buildings are shaded.

\begin{tabular}{|c|c|c|c|c|c|c|c|c|}
\hline & \multicolumn{4}{|c|}{ ceilings with attics } & \multicolumn{4}{c|}{ ceilings without attics } \\
\hline & \multicolumn{2}{|c|}{ wood frame } & \multicolumn{2}{c|}{ steel frame } & \multicolumn{2}{c|}{ wood frame } & \multicolumn{2}{c|}{ steel frame } \\
\hline $\begin{array}{c}\text { climate } \\
\text { zone }\end{array}$ & $\begin{array}{c}\text { conventional } \\
\text { roof }\end{array}$ & cool roof & $\begin{array}{c}\text { conventional } \\
\text { roof }\end{array}$ & cool roof & $\begin{array}{c}\text { conventional } \\
\text { roof }\end{array}$ & cool roof & $\begin{array}{c}\text { conventional } \\
\text { roof }\end{array}$ & \begin{tabular}{c} 
cool roof \\
\hline 1
\end{tabular} \\
30 & 20 & 30 & 20 & 13 & 10 & 19 & 10 \\
\hline 2 & 30 & 24 & 30 & 24 & 22 & 17 & 19 & 17 \\
\hline 3 & 30 & 27 & 30 & 27 & 22 & 18 & 22 & 22 \\
\hline 4 & 38 & 38 & 38 & 38 & 22 & 22 & 22 & 26 \\
\hline 5 & 43 & 43 & 43 & 43 & 26 & 26 & 38 & 26 \\
\hline 6 & 49 & 49 & 49 & 49 & 38 & 38 & 38 & 38 \\
\hline 7 & 49 & 49 & 49 & 49 & 38 & 38 & 38 & 38 \\
\hline 8 & 52 & 52 & 52 & 52 & 38 & 38 & 38 & 38 \\
\hline
\end{tabular}

Table 8. Solar reflectance and thermal emittance requirements of a current (2007) residential cool-roof rebate program administered by two California utilities (Pacific Gas \& Electric, Southern California Edison).

\begin{tabular}{|c|c|c|c|c|}
\hline $\begin{array}{c}\text { roof } \\
\text { slope }\end{array}$ & $\begin{array}{c}\text { rebate } \\
\text { tier }\end{array}$ & $\begin{array}{c}\text { initial solar } \\
\text { reflectance }\end{array}$ & $\begin{array}{c}\text { initial } \\
\text { thermal } \\
\text { emittance }\end{array}$ & rebate $\left(\$ / \mathrm{ft}^{2}\right)$ \\
\hline & & & & \\
\hline low $^{\mathrm{a}}$ & N/A & $\geq 0.70$ & $\geq 0.75$ & 0.20 \\
\hline steep $^{\mathrm{b}}$ & Tier 1 & $0.25-0.39$ & $\geq 0.75$ & 0.10 \\
\hline steep $^{\mathrm{b}}$ & Tier 2 & $\geq 0.40$ & $\geq 0.75$ & 0.20 \\
\hline
\end{tabular}

a. Ratio of rise-to-run less than or equal to $2: 12$

b. Ratio of rise-to-run greater than 2:12 
Evolution of cool roof standards in the United States

submitted to Advances in Building Energy Research, 2007-06-15

Accepted for publication, August 2007.

Table 9. Life-cycle cool-roof savings per unit roof area (cooling equipment savings plus 30-year net present value of energy savings with time dependent valuation; $\$ / \mathrm{m}^{2}$ ) by California climate zone for a nonresidential building with a steep-sloped roof Cool fiberglass asphalt shingles were assigned a solar reflectance of 0.25 ; cool concrete tiles and metal products, 0.40 ; and all conventional products, 0.10 .

\begin{tabular}{|c|c|c|c|}
\hline climate zone & shingle & tile & metal \\
\hline 1 & 2.8 & 4.8 & 5.8 \\
\hline 2 & 5.9 & 10.4 & 12.0 \\
\hline 3 & 4.7 & 8.2 & 9.6 \\
\hline 4 & 6.3 & 11.3 & 12.8 \\
\hline 5 & 5.1 & 8.9 & 10.4 \\
\hline 6 & 10.1 & 17.8 & 20.7 \\
\hline 7 & 9.1 & 15.8 & 18.7 \\
\hline 8 & 11.6 & 20.4 & 23.9 \\
\hline 9 & 11.9 & 20.8 & 24.4 \\
\hline 10 & 8.6 & 15.6 & 17.5 \\
\hline 11 & 7.4 & 13.5 & 15.1 \\
\hline 12 & 6.9 & 12.5 & 14.0 \\
\hline 13 & 8.3 & 15.3 & 17.0 \\
\hline 14 & 9.1 & 16.6 & 18.5 \\
\hline 15 & 11.4 & 21.2 & 23.3 \\
\hline 16 & 5.2 & 9.2 & 10.6 \\
\hline
\end{tabular}


Evolution of cool roof standards in the United States

submitted to Advances in Building Energy Research, 2007-06-15

Accepted for publication, August 2007.

Table 10. Life-cycle cool-roof savings per unit roof area (cooling equipment savings plus 30year net present value of energy savings with time dependent valuation; $\$ / \mathrm{m}^{2}$ ) by California climate zone for a residential building with a low-sloped roof. The cool roof was assigned a solar reflectance of 0.55 ; the conventional roof, 0.10 . We note that while California's Title 24 Standards prescribe the installation of sub-roof radiant barriers for residential buildings in California climate zones 2, 4, and 8-15, it is not a common building practice for homes with lowsloped roofs. The shaded values are appropriate to each climate zone's radiant-barrier requirement.

\begin{tabular}{|c|c|c|}
\hline California climate zone & without radiant barrier & with radiant barrier \\
\hline 1 & -2.4 & -2.5 \\
\hline 2 & 1.9 & -0.1 \\
\hline 3 & -0.4 & -1.1 \\
\hline 4 & 0.9 & -0.4 \\
\hline 5 & -0.6 & -1.4 \\
\hline 6 & 0.7 & -0.2 \\
\hline 7 & 1.2 & -0.1 \\
\hline 8 & 2.9 & 0.9 \\
\hline 9 & 4.2 & 1.8 \\
\hline 10 & 5.9 & 2.5 \\
\hline 11 & 5.3 & 2.5 \\
\hline 12 & 4.2 & 1.6 \\
\hline 13 & 5.9 & 3.0 \\
\hline 14 & 4.9 & 2.1 \\
\hline 15 & 8.2 & 4.7 \\
\hline 16 & 2.3 & 0.1 \\
\hline
\end{tabular}


Evolution of cool roof standards in the United States

submitted to Advances in Building Energy Research, 2007-06-15

Accepted for publication, August 2007.

Table 11. Life-cycle cool-roof savings per unit roof footprint area (cooling equipment savings plus 30-year net present value of energy savings with time dependent valuation; $\$ / \mathrm{m}^{2}$ ) by California climate zone for a residential building with a steep-sloped roof. Cool fiberglass asphalt shingles were assigned a solar reflectance of 0.25 ; cool concrete tiles and metal products, 0.40; and all conventional products, 0.10 . While California's Title 24 Standards prescribe the installation of sub-roof radiant barriers for residential buildings in climate zones 2,4 , and 8-15, it is was a common practice in pre- 2000 construction The shaded values are appropriate to each climate zone's radiant-barrier requirement.

\begin{tabular}{|c|c|c|c|c|c|c|}
\hline \multirow{2}{*}{ California climate zone } & \multicolumn{3}{|c|}{ without radiant barrier } & \multicolumn{3}{c|}{ with radiant barrier } \\
\cline { 2 - 7 } & shingle & tile & metal & shingle & tile & metal \\
\hline 1 & -0.9 & -1.7 & -1.7 & -0.6 & -1.2 & -1.3 \\
\hline 2 & 2.2 & 3.0 & 5.0 & 1.3 & 2.2 & 2.9 \\
\hline 3 & 0.2 & 0.2 & 0.5 & 0.1 & 0.1 & 0.3 \\
\hline 4 & 0.9 & 1.1 & 2.2 & 0.5 & 0.9 & 1.2 \\
\hline 5 & 0.4 & 0.2 & 0.9 & 0.2 & 0.1 & 0.4 \\
\hline 6 & 0.7 & 1.0 & 1.7 & 0.5 & 0.6 & 1.0 \\
\hline 7 & 1.2 & 1.7 & 2.7 & 0.7 & 1.0 & 1.4 \\
\hline 8 & 3.1 & 4.5 & 6.8 & 1.8 & 2.9 & 3.9 \\
\hline 9 & 3.5 & 5.4 & 7.7 & 2.2 & 3.7 & 4.8 \\
\hline 10 & 5.7 & 8.9 & 12.4 & 3.5 & 5.9 & 7.3 \\
\hline 11 & 5.5 & 8.8 & 12.2 & 3.5 & 6.1 & 7.6 \\
\hline 12 & 3.7 & 5.8 & 8.2 & 2.4 & 4.1 & 5.2 \\
\hline 13 & 6.8 & 11.1 & 14.8 & 4.1 & 7.4 & 8.8 \\
\hline 14 & 5.3 & 8.3 & 11.5 & 3.3 & 5.7 & 7.0 \\
\hline 15 & 8.5 & 13.8 & 18.6 & 5.6 & 9.8 & 12.1 \\
\hline 16 & 2.8 & 4.5 & 5.9 & 1.6 & 2.6 & 3.3 \\
\hline
\end{tabular}


Evolution of cool roof standards in the United States

submitted to Advances in Building Energy Research, 2007-06-15

Accepted for publication, August 2007.

Figure 1. Locations of the eight ASHRAE-defined climate zones in the United States (ASHRAE 2007).

Figure 2. Locations of the 16 California climate zones (courtesy Eley Associates).

Figure 3. Total savings per unit roof area (cooling equipment savings plus 15 -year net present value of energy savings with time-dependent valuation; $\$ / \mathrm{m}^{2}$ ) by California climate zone, simulated for a prototypical nonresidential Title 24 building with a cool low-sloped roof.

Figure 4. Adoption of commercial building energy codes by U.S. states as of May 2007. Courtesy Building Codes Assistance Project (BCAP 2007).

Figure 5. Adoption of residential building energy codes by U.S. states as of May 2007. Courtesy Building Codes Assistance Project (BCAP 2007). 


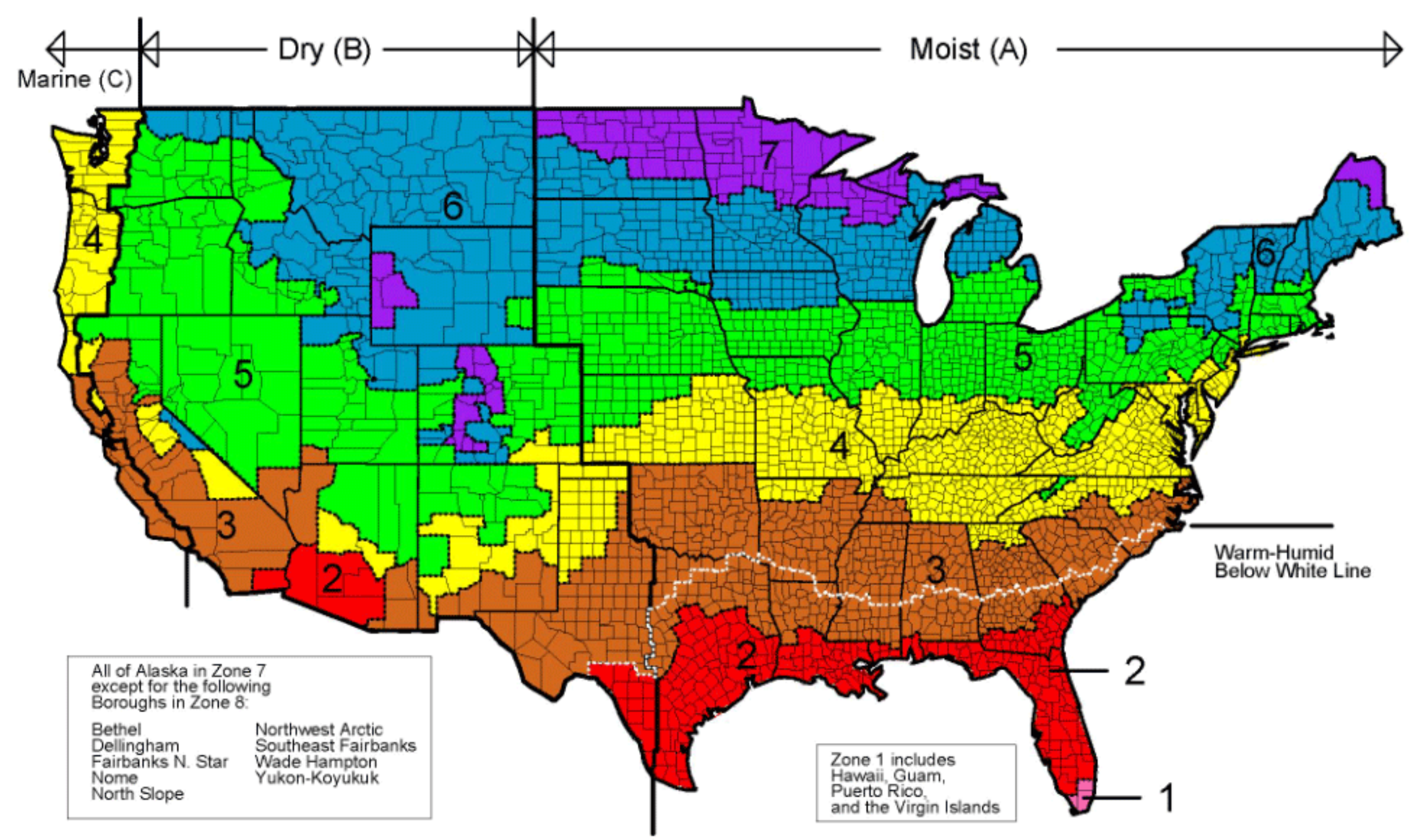




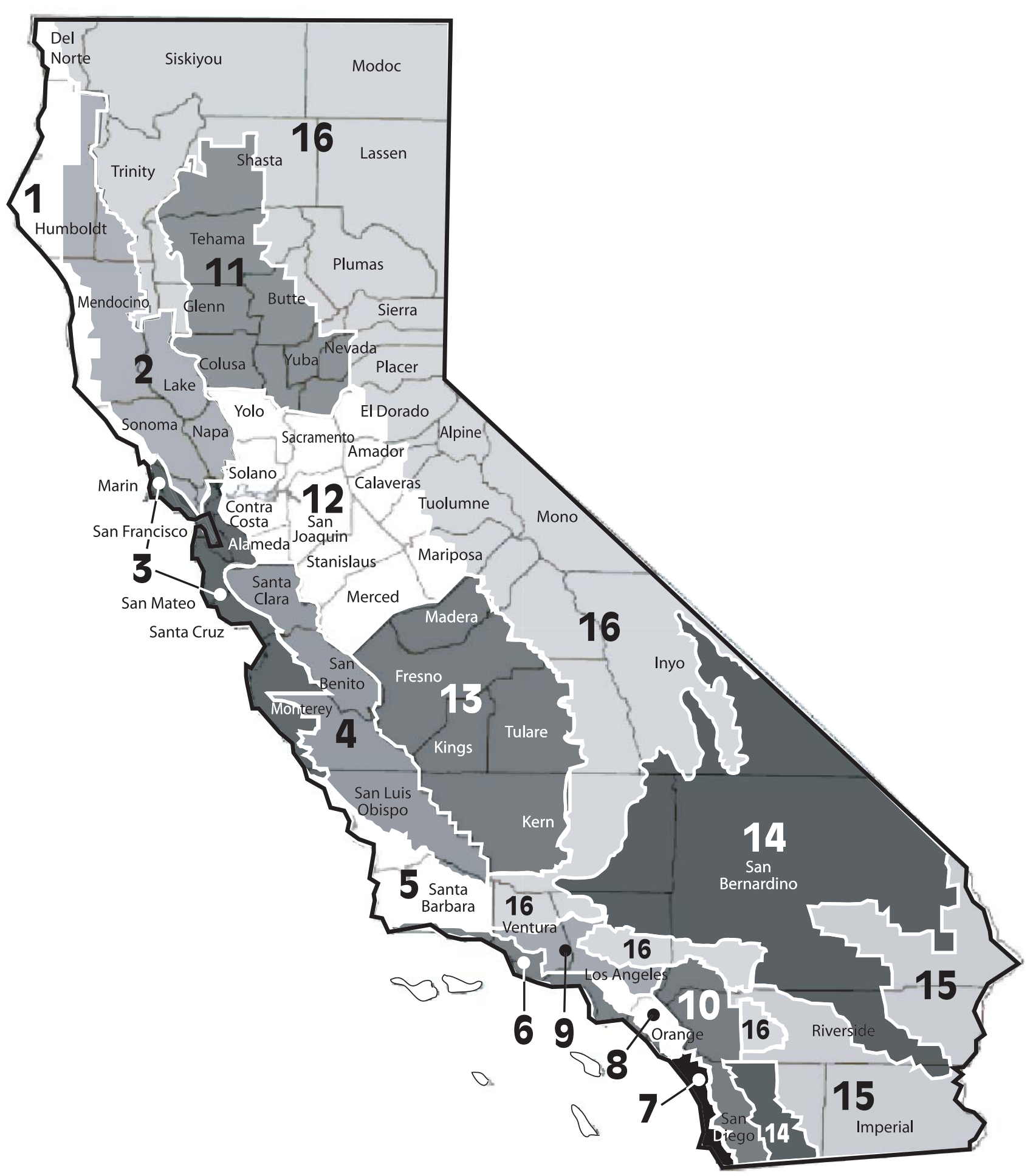




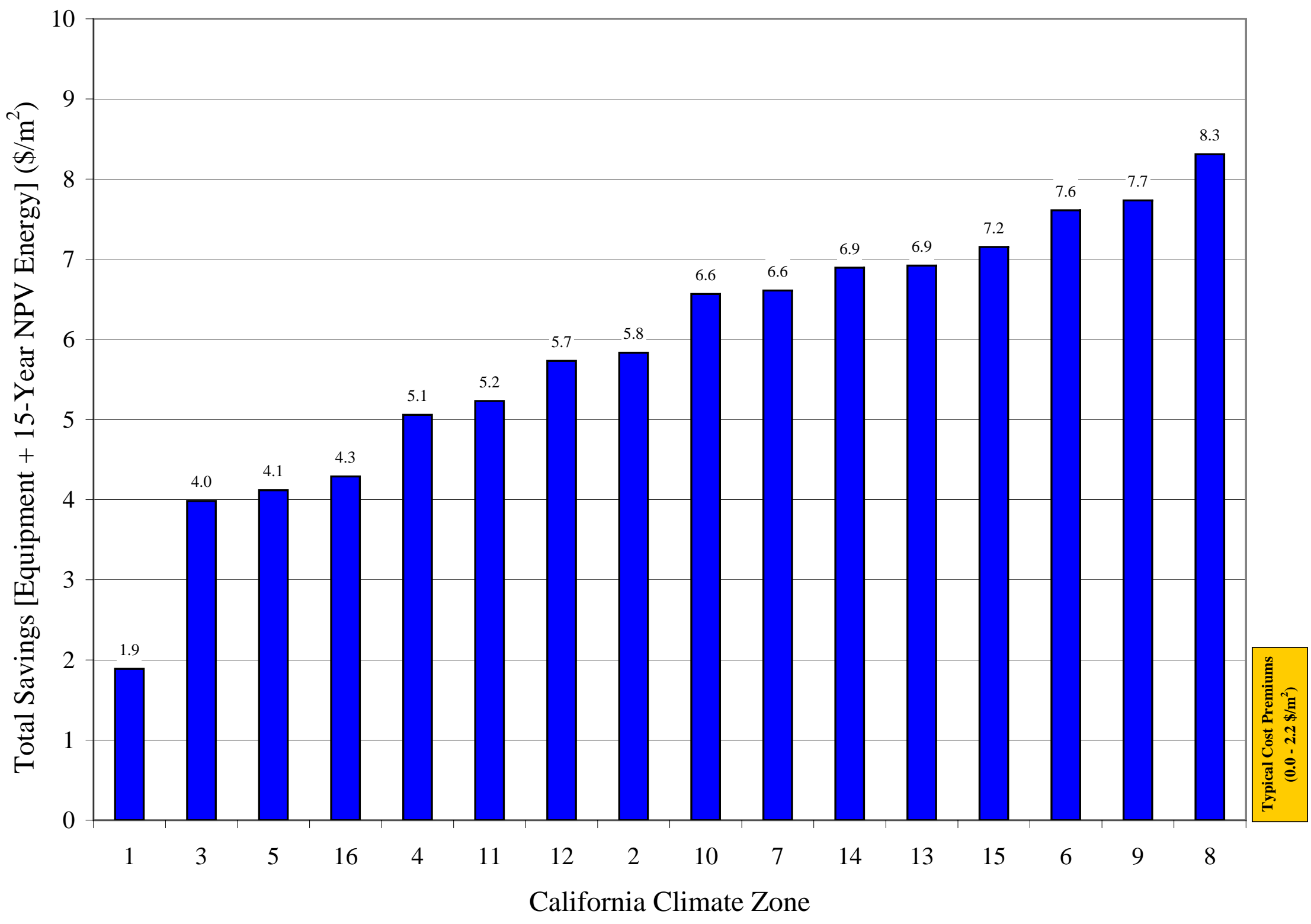

